W. PREVENIER

\title{
DE BEDEN IN HET GRAAFSCHAP VLAANDEREN ONDER FILIPS DE STOUTE
}

$$
\text { (1:384-1404) }
$$

Overdruk uit de Revue belge de Philologie et d'Histoire t. XXXVIII, 1960, No 2 


\section{DE BEDEN IN HET GRAAFSCHAP VLAANDEREN ONDER FILIPS DE STOUTE

\author{
(1384-1404)
}

Met oprechte dank aan mijn leermeester Prof. Dr. H. Van Werveke opgedragen

Op het einde der middeleeuwen dekten de openbare financiën en het persoonlijk patrimonium van de vorst elkaar nog volledig. Het belastingstelsel in Vlaanderen tijdens de jaren 1384-1404 werd bijgevolg niet enkel gedetermineerd door de politieke, militaire en economische ambities en handelingen van de hertog als vorst, doch tevens door diens privaat leven. De militaire interventies in Gelre (1388), in Vlaanderen zelf (liquidatie van de opstand van 1379-85), de kust-defensie tegen Engeland en tegen zeeroversraids, de kruistocht naar Hongarije (1394) en de losprijs van de aldaar door de Turken gevangen genomen hertogszoon (1397), vormden uitermate zware lastposten op het budget van de vorst. Nog andere elementen evenwel brachten het fin anciële evenwicht in het gedrang.

(*) We danken van harte Prof. Dr. H. Van Werveke, die zo vriendelijk was deze tekst te willen doornemen. Dit artikel is gegroeid uit de licentiaatsverhandeling over de Leden en Staten van Vlaanderen, die we onder zijn leiding tot stand brachten.

Gebruikte sigla :

A.D.N., Lille, B = Archives Départementales du Nord, Lille, Serie B.

A.G.N.

$=$ Algemene Geschiedenis der Nederlanden.

A.R.A., R.K.

$=$ Algemeen Rijksarchief (Brussel), Rekenkamer.

Trés. de Fl.

$=$ Trésor de Flandre.

B.N., Paris, Coll. Bourg. = Bibliothèque Nationale, Paris, Section des Manuscrits, Collection Bourgogne.

H.L.St.

$=\mathrm{W}$. Prevenier, Handelingen van de Leden en van de Staten van Vlaanderen (1384-1405), Kon. Comm. voor Gesch., 4º-reeks, Brussel, 1959.

K.B., Hs. Cab.

$=$ Koninklijke Bibliotheek Brussel, Handschriften Cabinet.

S.A.B.

$=$ Stadsarchief Brugge.

S.A.G.

$=$ Stadsarchief Gent. 
Filips de Stoute was zeer tuk op uiterlijk vertoon $\left({ }^{1}\right)$, op pracht en praal $\left({ }^{2}\right)$ en bovendien onverbeterlijk aan het spel verslaafd $\left({ }^{3}\right)$. Deze karaktertrekken brachten, mede met zijn grote politieke ambities, de vorst in een schier permanente geldnood. De gehele duur van zijn bewind over Vlaanderen (zoals trouwens reeds voordien) vernemen we er de weerklank van : de snel-opeenvolgende beden, evenals de nadrukkelijke wens die de hertog daarbij telkens formuleerde om zo spoedig mogelijk de voorziene sommen te zien samenbrengen $\left({ }^{4}\right)$, vormen overduidelijke aanduidingen. Af en toe nochtans meende deze vorst, voor wie het luisterrijk optreden tot een inhaerent bestanddeel van zijn diplomatie geworden was, voor bepaalde gebeurtenissen op besparingen te moeten aandringen $\left(^{5}\right)$. Schijnbare paradox, die in feite

(1) Dit was de Vlamingen reeds duidelijk geworden bij de luisterrijke plechtigheden die in 1369 met zijn huwelijk met Margareta van Male gepaard gingen (E. Petit, Itinéraires de Philippe le Hardi et de Jean sans Peur, ducs de Bourgogne (1363-1419) d'après les comptes de dépenses de leur hôtel, Collection DES Documents inédits sur l'histoire de France, Paris, 1888, pp. 478-80 ; B. en H. Prost, Inventaires mobiliers et extraits des comptes des ducs de Bourgogne de la maison de Valois (1363-1477) bd. I, fasc. 1, Paris, 1902, pp. 175-184; A. G. DE Barante, Histoire des ducs de Bourgogne de la maison de Valois, bd. I, Bruxelles, 1835, p. 89). Ook hertogin Margareta leidde een koninklijk hofleven (M. Canat, Marguerite de Flandre, duchesse de Bourgogne, sa vie intime et l'état de sa maison, Paris, 1860, pp. 8-9 ; uitgaven per jaar: pp. 136-9).

(2) P. FredericQ, Essai sur le rôle politique et social des ducs de Bourgogne dans les Pays-Bas, Gand, 1875, pp. 52-53; H. David, Philippe le Hardi au début du $X V^{\text {e }}$ siècle in Annales de Bourgogne, bd. XVI, 1944, vnl. pp. 201-228; A. van Zuylen van Nyevelt, Épisodes de la vie des ducs de Bourgogne à Bruges, Bruges, s. d. (1937), pp. 83-89.

(3) van Zuylen van Nyevelt, Épisodes, p. 89 ; O. Cartellieri, Philipp der Kühne, Geschichte der Herzöge von Burgund (1363-147\%), bd. I, Leipzig, 1910, p. 61 ; J. J. Vernier, Philippe le Hardi, duc de Bourgogne, sa vie intime, Mém. Soc. académique de l'Aube, bd. LXIII, 1899, pp. 29-63.

(4) A.R.A., Trés. de Fl., 1 e serie, no 2.212 (4 aug. 1397) : auxquels commissaires nous avons escript et mandé tres expressement que la tierce partie pour le premier paiement de la dicte somme soit tantost imposee sur les dictes villes et parroisses et telement avancié que l'argent soit prest.

(5) B.N., Coll. Bourg., no 26, fo 80r (23 april 1392) : persoonlijke brief van Filips aan zijn echtgenote. Margareta klaagde er over dat ze over onvoldoende sommen beschikte om haar schoonzoon, hertog Leopold IV van Oostenrijk, behoorlijk te ontvangen. Filips replikeert: nous ne voulons pas grans frais et missions estre fais 
bewijst dat Filips behendig genoeg was om de praal te reserveren voor omstandigheden die nuttig waren voor zijn prestige (1). Ze toont bovendien aan dat hij toch meer dan eens te breed met zijn inkomsten omgesprongen was, zodat leningen en andere noodoplossingen zich onvermijdelijk opdrongen. Tekenend detail : in 1390 staan de Staten van Bourgondië Filips de Stoute een bede toe op voorwaarde echter dat de hertog expliciet belooft de $2 / 3$ van het totale bedrag voor het betalen van zijn schulden te zullen aanwenden, en slechts $1 / 3$ pour faire son plaisir ${ }^{(2)}$.

Op het einde van zijn regering werd de financiële positie nog benarder. In 1401-1402 en 1403-1404 overtroffen de uitgaven aanzienlijk de inkomsten $\left({ }^{3}\right)$. Bij Filips' afsterven, op 27 april 1404 te Halle, bleef dan ook een weinig eervolle nalatenschap van talrijke schulden achter. Tijdens de begrafenisplechtigheden deed zich trouwens een bekende gebeurtenis voor, die de scherpe financiële nood waarmee Filips zijn regering afsloot treffend illustreert : zijn weduwe Margareta

pour la venue de nostre dit fils, ne aussi n'est il aucun besoing, attendu que les noces et solemnization de mariage, ont esté faittes assez solemnellement, ne que aussi l'en mande pour ce moult de dames, ne de chevaliers, fors seulement des plus prochains de vous.... Zelfs de duur van het bezoek wordt bij voorbaat vastgesteld, op ten hoogste drie dagen! Tenslotte bepaalt Filips reeds het maximum-bedrag dat men mag uitgeven : ... et ne voulons que l'en despende pour ce fait cy oultre la somme de II $I^{M}$ frans.

(1) Dit was o.m het geval, wat Vlaanderen betreft, in 1369 bij de huwelijksvoltrekking te Gent, en in jan. 1386 bij zijn blijde intocht te Gent(B.N., Coll. Bourg., $\mathrm{n}^{\circ} 26$, f० $\left.311^{\mathrm{r}}\right)$.

(2) B.N., Coll. Bourg., no 101, fo $85^{\mathrm{v}}$ (23 febr. 1390) : een bede van $30.000 \mathrm{Fr}$. wordt door de Staten van Bourgondië toegestaan, de laquelle somme il ne pourroit disposer que de $10.000 \mathrm{Fr}$. pour faire son plaisir et les 20.000 seroient employés d̀ payer ses debtes.

(3) A. Coville, Les finances des ducs de Bourgogne au commencement du XVe siècle, Etudes d'Hist. du Moyen-Age offertes à G. Monod, Paris, 1896, p. 412. In 1400-1401 was de balans wel wat gunstiger en vertoonde ze een boni van $3.344 \mathrm{lb}$. 1s. 9d. tourn. ; in 1401-1402 bedroeg het deficit echter meer dan $48.000 \mathrm{lb}$., en in 1403-1404 meer dan $67.000 \mathrm{lb}$. Ter verklaring kunnen o.m. ingeroepen worden, de weigeringen tot beden in Vlaanderen na 1397 en het verlagen der inkomsten in Bourgondië na 1396 (B. A. PocQuet DU Haut-Jussé, Les Aides en Bourgogne sous Philippe le Hardi et Jean 'sans Peur, Revue Historique de Droit français et étranger, jg. 1939, p. 418). Men moet anderzijds toegeven dat Filips naar het einde toe zijn persoonlijke uitgaven sterk snoeide (Coville, Les finances, pp. 408-409). 
wierp toen namelijk op de lijkbaar met het stoffelijk overschot van haar man, sleutels en beurs neer, om aan te tonen dat ze afstand deed van alle roerende goederen die Filips haar naliet, schulden incluis $\left(^{1}\right)$. Deze handeling wordt bevestigd door een schriftelijke verklaring van 9 mei $1404\left({ }^{2}\right)$, waardoor ze verder op 12 mei 1404 al de gemeenschappelijke bezittingen aan haar zoon, Jan zonder Vrees, overmaakte $\left(^{3}\right)$.

In dit licht krijgt de cynische opmerking die een kroniekschrijver, na een panegyrische uitlating bij de dood van de hertog, zich over diens financiële politiek veroorloofde een zeer reële klank : Au dit an mourut Philipes, duc de Bourgogne, dit le Hardy, que on tenoit vaillant, sage et prudent, et estoit prince de grant louange très aymé, payoit comme on disoit tant que tous ses meubles n'eussent pas souffis à payer ses debtes $\left(^{4}\right)$.

\section{$* *$}

Door het beheer van verschillende territoria beschikte Filips de Stoute over talrijke bronnen van inkomsten van uiteenlopende aard in elk van deze gebieden $\left(^{5}\right)$ : domaniale opbrengsten, allerlei directe belastingen, tollen, beboetingen en compositiones, kortom de recette ordinaire. Bovendien mag men een aantal andere belangrijke bronnen niet uit het oog verliezen.

(1) E. de Monstrelet, Chronique (1400-1444), Soc. Hist. de France, bd. I, Paris, 1857, p. 89. Zie de opmerking die Cartellieri hierbij makkt (Philipp der Kühne, p. 110).

(2) B. N., Coll. Bourg., no 95, p. 227. Zie ook Dom U. Plancher, Histoire générale et particulière' de Bourgogne avec preuves justificatives, bd. III, Dijon, 1748, Preuves, p. Gaxix (nr. GcxviII).

(3) B.N., Coll. Bourg., no 54 , fo $76^{r}$.

(4) B.N., Coll. Bourg., $\mathrm{n}^{\circ} 54$, fo $82^{\mathrm{r}}$. Deze tekst stemt \pm overeen met hetgeen te vinden is bij J. Juvenal des Ursins, Histoire de Charles VI, roi de France, Paris, 1653 , p. 158.

(5) Problemen in dit verband vormen het thema van een voortreffelijke studie van Mej. A. Van Nieuwenhuysen, Le Transport et le Change des Espèces dans la Recette Générale de toutes les Finances de Philippe le Hardi in R.B.P.H., bd. XXXV, 1957, pp. 55-65. Er moge hier gewezen worden op het grote belang van de opvolging in Vlaanderen voor de financiën van Filips de Stoute. Door deze erfenis stegen zijn inkomsten met $1 / 3$ tot $2 / 3$ ten overstaan van 1383 (M. Mollat, Recherches sur les finances des ducs Valois de Bourgogne in Revue historique, bd. CCXIX, 1958, pp. 309-313). 
In Vlaanderen zelf kon de hertog met name rekenen op de vaste jaarlijkse belastingen, bekend onder de naam «Transport»( $\left.{ }^{1}\right)$. De oorsprong lag in één der clausules van het verdrag van Athis-sur-Orge (1305), dat de Vlamingen o.m. tot een jaarrente van $20.000 \mathrm{lb}$. tournois aan de Franse vorst verplichtte $\left({ }^{2}\right)$; na de afstand van WaalsVlaanderen aan Frankrijk (transport) door Robrecht van Bethune, dienden ze voortaan de helft van de rente, nl. $10.000 \mathrm{lb}$. tournois, als annuïteit aan hun eigen vorst te storten terwijl de andere helft vervangen was door een globale storting aan de Franse vorst $\left({ }^{3}\right)$. De bekende repartitietabel ca. $1309\left(^{4}\right)$ met het oog op deze betalingen opgesteld, werd onder Filips de Stoute nog steeds integraal toegepast $\left(^{5}\right)$. Het totale bedrag $(10.000 \mathrm{lb}$. tournois of $8.000 \mathrm{lb}$. par.) was echter niet behouden gebleven, daar o.m. Gent zijn bijdrage tussen 1323 en 1326 had gekapitaliseerd, waardoor zijn rente definitief wegviel $\left({ }^{6}\right)$. Theoretisch was de inningsdatum op midwinter $(25$ december $)$

(1) Onder Filips de Stoute duidt men ze aan als Transport van Rijsel, Dowaai en Orchies (A.R.A., R.K., no 42.525, fo $4^{\mathrm{v}-5^{\mathrm{r}} \text { ) }}$ of Transport van Rijsel, Dowaai en Béthune (L. Gilliodts-van Severen, Inventaire des archives de la ville de Bruges, bd. III, Bruges, 1875, pp. 34-35). Dit laatste is een verouderde reminiscentie, vermits in feite in 1311 de kasselrij Béthune bij Artesië was gekomen, en in alle stukken officieel vervangen was door deze van Orchies (J. Buntinx, De audientie van de graven van Vlaanderen, Verhand. v. D. Kon. Vl. Ac. voor Wet. Lett. eN Sch. K. v. Belg., Brussel, 1949, p. 225).

(2) H. VAN Werveke, Les charges financières issues du traité d'Athis (1305) in Rev. du Nord, bd. XXXII, 1950, p. 81.

(3) Van Werveke, o. c., pp. 85-90.

(4) D. Berten, Coutumes des pays et comté de Flandre. Quartier de Gand, bd. VII, Bruxelles, 1904, pp. 20-22 betoogt dat het document van 1317 en niet van 1309 dateert; de uitgave van Gilliodts-van Severen (Inv., IV, pp. 279-80) en Th. DE Limburg Stirum (Codex Diplomaticus Flandriae inde ab anno 1296 ad usque 1327 in Uitg. v. h. Genootsch. voor Gesch. Soc. d'Émul. te Brugge, bd. II, Bruges, 1889, pp. 141-43) vermelden nochtans expliciet 1309. Een kritisch onderzoek van deze kwestie ware ten zeerste gewenst.

(5) Brugge betaalde jaarlijks $1.217 \mathrm{lb}$. par. (Gilliodts-van Severen, o. c., bd. III, pp. 107, 126, 248, 271, 349, 392, 404 en 446), het Vrije 1.067 lb. par. (A.R.A., R. K., no $42.521-42.528$, telkens fo $4^{\mathrm{v}}$ of $5^{\mathrm{r}}$ ), dit zijn precies de quota van de tabel (resp. 15,20 en $13,33 \%$ ).

(6) H. Van Werveke, De"Gentsche Stadsfinanciën in de Middeleeuwen, Brussel, 1934, p. 322 . 
vastgesteld. In feite hield men zich allerminst aan deze regeling $\left.{ }^{(}\right)$.

Merkwaardig is verder de grote financiële steun die Filips de Stoute vanwege de stad Brugge ervaren mocht. De stad stemde toe in een belangrijke verhoging van haar quotum volgens het Transport voor elk der algemene beden $\left({ }^{2}\right)$. Bovendien verstrekte zij de vorst gewichtige leningen, toen deze in grote financiële nood verkeerde, buiten de andere Leden om $\left({ }^{3}\right)$. Vanzelfsprekend bracht deze inschikkelijkheid ook bij gelegenheid tegenprestaties mee vanwege de hertog $\left(^{4}\right)$.

Naast leningen kon de vorst tevens rekenen op vrijwillige geschenken (dons), die zich onderscheiden van de beden door het particulier karakter van het verzoek en de persoonlijke aard der motieven. Deze dons worden immers door de vorst afzonderlijk bij elk der steden en gebieden aangevraagd en er is geen sprake van een algemene globale som, noch van enige repartitie. De door de vorst voorgestelde motieven dragen een zeer persoonlijk, bijna louter familiaal karakter. Bekend zijn met name de geschenken naar aanleiding van het dubbel huwelijk te Kamerijk in $1385\left(^{5}\right)$, en het huwelijk van Antoon van Bour-

(1) Storting verschilde van stad tot stad. Soms betaalde men te vroeg (GILLIodts-van Severen, o. c., bd. III, pp. 126, 404, 496), soms te laat (ID., p. 107 ; A.R.A., R.K., $\mathrm{n}^{\circ} 42.527$, fo $4^{\mathrm{v}}$, en $5^{\mathrm{r}}$,). Ook stortte men wel eens het bedrag van twee annuïteiten in eens (A.R.A., R.K., Rolrek. no 1992, vooraan de rol).

(2) Zie bijlage I (vgl. de sommen onder n ${ }^{\circ} 1$ van de synoptische tabel).

(3) In 1394 verleende Brugge een som van $10.000 \mathrm{Fr}$. voor de bouw van de fameuze toren van Bourgondië te Sluis (A.R.A., Trés. de Fl., 1e serie, nº 561 ; A.D.N., B. 1348, no 13.336bis ; Gilliodts-van Severen, o. c., III, pp. 277-281, 295, 345, 350). In 1404 een van 1.000 nobels, i.v.m. de pogingen van de hertog om de troonsafstand van de Brabantse vorstin ten voordele van zijn zoon te bewerken (GILLiodts-van Severen, o. c., p. 452 ; S. A. B., Rek. 1403-04, fo 102 ).

(4) In 1398 lost de hertog een voor Brugge hinderlijk conflict met de graaf van Sint-Pol op (Gilliodts-van Severen, o. c., p. 411). In 1396 verkreeg de stad, die momenteel in financiële moeilijkheden verkeerde, een belangrijke som vanwege de vorst om de Genuezen te kunnen betalen (A.R.A., Trés. de Fl., $1^{\text {e }}$ série, n $^{\circ} 563$ ) ; bovendien verzekerde de hertog het permanent aan de macht blijven van één zelfde kliek in de Brugse schepenbank, als beloning voor de fiscale inschikkelijkheid van deze groep (V. Fris, Het Brugsch Calfvel van 1407-1411, Bull. Acad. Roy. d'Arch. de Belg., 1911, p. 219) en vermoedelijk vormen deze gunsten de ongeschreven voorwaarden voor de permanentie van de bewindsploeg.

(5) A.R.A., R.K., n 6.890, Rek. J. de Streyhem, ontvanger van Biervliet en Harelbeke, 1387-1394, voorkaft en fo $14^{\mathrm{r}}$ : betalingen van achterstel nl. het Vrije 
gondië, zoon van Filips, en latere hertog van Brabant met Johanna van Sint-Pol in $1401\left(^{1}\right)$. Verder, in oktober 1384, een subsidie, voorgesteld deels als gift naar aanleiding van de Blijde Inkomst van de Bourgondische hertog, deels als oorlogsbelasting $\left({ }^{2}\right)$. De repartitie der quota van deze gift zag er als volgt uit :

$\begin{array}{ll}\text { Waasland } & 8.000 \mathrm{lb} \text {. par. } \\ \text { Land van Dendermonde } & 6.650 \mathrm{lb} \text {. par. } \\ \text { Brugse Vrije } & 1.680 \mathrm{lb} \text {. par. } \\ \text { Land van Bornem } & 1.800 \mathrm{lb} \text {. par. }\end{array}$

Bovendien betaalden in het graafschap Holland : Kennemerland en Waterland : $1.000 \mathrm{~F}$; en in Waals Vlaanderen de stad Rijsel : $3.600 \mathrm{~F}$, Douai : 3.100 F, kass. Rijsel : 2.000 lb., kass. Douai + Orchies : 800 lb., Orchies : $200 \mathrm{lb}$.

Buiten Vlaanderen verzekerden niet enkel Bourgondië $\left(^{3}\right)$ en andere bezittingen interessante inkomsten aan Filips de Stoute. Zijn rol aan het Franse hof en zijn invloed op de koning bezorgden hem in het koninkrijk een belangrijke supplementaire bron van financieel voordeel $\left(^{4}\right)$. Ononderbroken werden hem bijzondere pensioenen of

en Sluis elk 300 mark zilver (= $3.600 \mathrm{lb}$. par.), aangevuld met een supplement wegens stijgen van de koers van de frank van 42 gro. tot 48 gro. sedert 1385 (koers van mark zilver in 1385 : A.D.N., B. 4.073, fo 34 r). Over de bede voor de huwelijken van Jan zonder Vrees en Margareta van Bourgondië, zie enkele gegevens in : H. DAvid, Jeunesse de Jean, second duc de Valois de Bourgogne, in Miscellanea D. Roggen, Antwerpen, 1957, pp. 66-7. Over de huwelijken van Kamerijk: J. Schoos, Der Machtkampf zwischen Burgund und Orleans unter den Herzögen Philipp der Kühnen in Publ. Sect. hist. Inst. Gr.-Ducal de Lux., Luxembourg, 1956, pp. 45-58.

(1) Bijdrage in deze dons door het Vrije voor een totaal van 2.000 nobels (A.R.A., R.K., no 42.526 , fo $5^{\mathrm{v}}$ ) ; de lening van $5.148 \mathrm{lb}$. par., met hetzelfde doel, door Duinkerken, Kassel (stad + kasselrij), kasselrij Broekkurg, Poperinge, Sluis en het land van Aalst werd gestort op voorwaarde afgetrokken te mogen worden van de quota dezer steden in de eerstvolgende bede (A.D.N., B. 4.085, fo $50^{\mathrm{v}}$.). Over aandeel van Brugge (3.000 nobels aan $72 \mathrm{~s}$. par. Vlaams) zie : A.R.A., Trés. de Fl., $1^{\mathrm{e}}$ série, no 569 (22 sept. 1401) ; B.N., Coll. Bourg., n² 26, fo 105 ; Gilliodts-van Severen, o. c., bd. III, p. 443.

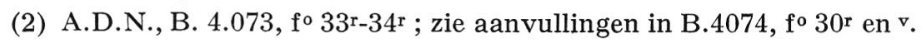

(3) Pocquet du Haut-Jussé, Les aides en Bourgogne, pp. 416-422.

(4) B.A. Pocquet du Haut-Jussé, Jean sans Peur. Programme, moyens et résul- 
belangrijke aandelen in de beden der Franse provincies toegestaan $\left(^{1}\right)$.

Toch is het zo dat, evenals elke laat-middeleeuwse vorst, Filips de Stoute te kampen had met steeds groeiende fiscale behoeften van het regeringsbeleid, met uitgaven, waartoe de klassieke vroeg-middeleeuwse bronnen van inkomsten niet meer volstonden. Vandaar de talrijke verzoeken om beden $\left({ }^{2}\right)$ die we thans behandelen willen, althans voor Diets-Vlaanderen $\left({ }^{3}\right)$ in de periode 1384-1404.

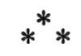

Wat impliceert precies het begrip bede? In de meeste gewesten werd bij de indirecte belastingen duidelijk onderscheid gemaakt tussen gewone en buitengewone beden $\left({ }^{4}\right)$. De eerste zijn belastingen opgelegd door de territoriale vorst aan de onder zijn jurisdictie vallende onderdanen ${ }^{5}$ ), doorgaans verstard tot een vaste, meestal jaarlijkse bij-

tats in Rev. de l'Univ. de Brux., bd. VII, 1954-55, pp. 390-393; Coville, Les finances, pp. 406-407; zie ook : B. N., Coll. Bourg., n० 101 , fo $86^{\mathrm{v}}$.

(1) B. A. Pocquet du Haut-Jussé, Les dons du Roi aux ducs de Bourgogne, Philippe le Hardi et Jean sans Peur (1363-1419) in Annales de Bourgogne, bd. X, 1938 , p. 268 en vlg.

(2) Vandaar ook pogingen van Filips om het heffen van beden in zijn territoria door andere personen zo sterk mogelijk te beperken; op 26 nov. 1397 verbiedt Filips aan Jan van Namen te Wijnendale en Ronse, qui sont assez chargiéz de payer leur part et porcion de l'ayde de cent mille nobles [van de hertog], enige supplementaire bede in diens privaat voordeel te heffen (A.R.A., Trés. de Fl., $1^{\mathrm{e}}$ serie, no 970) ; maakt niettemin uitzondering op 22 maart 1398 (Ibid., n ${ }^{\circ} 971$ ).

(3) Waals-Vlaanderen vormde in deze periode, hoewel sedert 1369 opnieuw door personele unie onder één zelfde vorst ressorterend, een bestuurlijk en fiscaal volstrekt aparte entiteit; een afzonderlijke behandeling van het Vlaamssprekende Vlaanderen is dus volstrekt verantwoord. In alle officiële streken van die periode werd de scheiding even strikt doorgedreven. Het toekennen der beden is in WaalsVlaanderen even autonoom (ten opzichte van Diets-Vlaanderen) als bv. in Artesië, Bourgondië of Nevers.

(4) C. Stephenson, Taxation and representation in the Middle Ages in Anniversary Essays in Mediaeval History by Students of Charles Homer Haskins, Boston, N.Y., 1929, pp. 302-312.

(5) R. SchröDer-von KüNssberg, Lehrbuch der deutschen Rechtsgeschichte, Berlin-Leipzig, 1932, p. 589 : die zunächst nicht auf Grund eines Rechtsanspruches gefordert... aber in der Regel nicht verweigert werden konnten. 
drage $\left({ }^{1}\right)$. De buitengewone of supplementaire beden, tallia, dona, auxilia, daarentegen vormen sedert de $\mathrm{XIII}^{\mathrm{e}}$ eeuw een nieuw aspect der openbare fiscaliteit : het zijn vrijwillige toelagen, op onregelmatige tijdstippen aan de vorst verleend door een autonome beslissing der betalende standen, vandaar de naam landständische Steuer ${ }^{2}$ ).

In Vlaanderen is van deze dubbelzinnigheid van de term bede geen sprake. Bede is steeds en exclusief aangewend in de tweede betekenis (vrijwillige subsidie), terwijl voor de vaste betalingen (zoals het Transport), andere formuleringen bestaan $\left({ }^{3}\right)$. De tijdgenoten noemden de bede onder Filips de Stoute subvencie $\left(^{4}\right)$ of seventie $\left({ }^{5}\right)$, hoewel men doorgaans vaag omschrijft met mijns heren ghelde $\left(^{6}\right)$ en de begherte van onsen gheduchten heere $\left({ }^{7}\right)$.

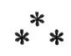

Het toekennen der beden was een der voornaamste prerogatieven van het Vlaamse representatieve college bij uitstek, de Vier Leden $\left(^{8}\right)$.

(1) P. Gonissen, Een buitengewone bede in Brabant onder hertog Hendrik III (1253) in B.C.R.H., bd. XXVIII, 1950, pp. 529-50; in Holland reeds in de $1 \mathrm{e}$ helft der xir eeuw (I. H. Gosses, Welgeborenen en huislieden. Onderzoekingen over standen en staat in het graafschap Holland, Groningen, 1926, p. 17).

(2) G. von Below, Die aelteste deutsche Steuer, Probleme der Wirtschaftsgeschichte. Eine. Einführung in das Studium der Wirtschaftsgeschichte, Tübingen, 1920, pp. 657658 ; Schröder-von Künssberg,. o. c., pp. 590 en 668. In Brabant zijn buitengewone beden speciale gunsten door de in financiële nood verkerende vorst gevraagd, in tegenstelling én met de vaste jaarbeden én met de feodale beden (J. Buntinx, De instellingen van de vorstendommen. De dertiende eeuw in A.G.N., bd. II, Utrecht, 1950, p. 369).

(3) Gosses (Welgeborenen, p. 18) meende ten onrechte op het bestaan van een vaste jaarbede in Vlaanderen te kunnen wijzen sinds \pm 1127 . Zie gewettigde kritiek door J. Buntinx in A.G.N., bd. II, p. 142, noot 2 .

(4) H.L. St., p. 284, r. 36.

(5) Id., p. 103, r. 12.

(6) K.B., Hs. Cab., Coll. Mergh, no 32, II, p. 158.

(7) H.L.St., p. 104 , r. 6.

(8) De befaamde Staten-historicus A. Thomas (Les États provinciaux de la France Centrale sous Charles VII, bd. I, Paris, 1879, p. 69) formuleerde het in algemene zin: La première attribution des États provinciaux en matière politique, c'est le vote de l'impôt; E. Duvernoy, Les États Généraux des duchés de Lorraine et de Bar jusqu'à la majorité de Charles III (1559), Paris, 1904, pp. 344-406 ; D. D. Brouwers, Les aides dans le comté de Namur au XVe siècle, Namur, 1929, p. xv. 
Deze beslisten onder Filips de Stoute autonoom en exclusief over het al of niet ingaan op het verzoek van de hertog, evenals over het vaststellen van het bedrag ( $\left.{ }^{1}\right)$. De andere betalende kleine steden en kasselrijen van Vlaanderen waren door deze toestemming der Leden, krachtens het gewoonterecht, absoluut gebonden, en beschikten over geen enkel wettelijk middel om zich hiertegen te verzetten $\left(^{2}\right)$. Ze waren overgeleverd aan de genade en de goede wil der Vier Leden.

Telkens de hertog het graafschap met een buitengewone bijdrage wenste te belasten stuurde hij een verzoekschrift — «bede» stricto sensu - tot de Vier Leden. Dit document bevatte een convocatie tot een vergadering ad hoc hetzij met de vorst persoonlijk $\left({ }^{3}\right)$, hetzij met de hertogin $\left({ }^{4}\right)$ of een andere overheidsinstantie $\left({ }^{5}\right)$ in zijn naam. Op deze zitting werd door het staatshoofd het verzoek gemotiveerd en met passende redenen omkleed, die de Leden tot een gunstig advies beoogden te bewegen $\left.{ }^{6}\right)$. Bleken deze laatsten inderdaad tot een dergelijke fiscale operatie geneigd, dan bestond de verdere discussie hoofdzakelijk in het bepalen van het bedrag. De hertog vertrok van een zo hoog mogelijk bedrag. De Leden dongen er zo veel mogelijk op af. In de meeste gevallen diende Filips de Stoute zich dan ook bij het prijs-

(1) A.D.N., B. 1273, no 11.584 (mei 1386) : les quelx VIM frans furent ordinés et ottroyés par les villes de Gand, Brughes et Ypre et le terroir du Franc en la presence du conseil estant à Gant.

(2) A.D.N., B. 865, n 14.582 (maart 1398) : Et aussi est acostumé voz bonnes villes et terroir (d.i. de Vier Leden) en subventions et charges de vostre pays par leur consentement obligier toutes les aultres villes de vostre pays de Flandres; cf. A. F. Pollard, The Evolution of Parliament, London, 1920, p. 143. Ook de aanspraak van de vorst op beden kan als een vorm van gewoonterecht beschouwd worden (Gosses, Welgeborenen, p. 32).

(3) S.A.B., Stadsrek., 1391-92, fo $62^{\mathrm{v}}$ (18 sept. 1391): Brugge zendt zijn gezanten naar Aergely in Bourgoengnen met den ghedeputeirden van den andren steden ende van dien van den Vrijen up tfait van der subventie.

(4) A.R.A., R.K., no 42.527, fo $50 \mathrm{v}-51^{\mathrm{r}}$ (9 sept. 1403) : onse voorseyde gheduchte vrauwe versochte van ons gheduchts heren weghe te hebbene van den lande van Vlaendre eene subvencie.

(5) Id., no 42.524 , fo $26^{\text {r }}$ (22 mei 1400) : overleg der Leden met de zoon van de vorst.

(6) Een omstandig verslag nopens dergelijke onderhandelingen (i.v.m. bede van $1394)$ is vastgelegd in een papieren cahier : A.D.N., B. 1276, no 12.987. Zie ook : A.D.N., B. $18.822, \mathrm{n}^{\circ} 23.410^{\mathrm{a}}$. 
geven van een belangrijk procent neer te leggen. Niet steeds konden of wilden de gezanten der Vier Leden op de zitting zelf beslissen; zij gaven er dan de voorkeur aan eerst met hun respectievelijke opdrachtgevers - de magistraten - overleg te plegen $\left(^{1}\right)$. In de drie steden wordt de zaak besproken door de voltallige schepenbanken; als voorzorgsmaatregel beleggen de Leden in enkele gevallen bovendien met de kleine steden en kasselrijen van hun kwartier vergaderingen $\left(^{2}\right)$, die overigens hoofdzakelijk informatorisch van karakter moeten geweest zijn, vermits de uiteindelijke beslissing bij de Leden lag. In het Brugse Vrije wordt een uitgebreide zitting geconvoceerd waarop naast de eigen schepenen tevens vertegenwoordigers der belastingbetalende bevolking (vrijlaten uit de diverse ambachten, proostlaten, kanunniklaten) geraadpleegd worden nopens de wenselijkheid van de gevraagde bede $\left({ }^{3}\right)$. Na dit particulier overleg komt het college der Leden opnieuw samen en maakt de vorst dan gunstig of ongunstig advies over $\left({ }^{4}\right)$. Tijdens de onderhandelingen hebben zowel de vorst (of zijn gezant) als de Leden hun respectievelijke belangen met veel tactische behendigheid behartigd. Indien een bepaalde stad een weigerige houding aanneemt, wordt deze onmiddellijk door de vorstin in afzonderlijke audiëntie ontvangen $\left(^{5}\right)$, om een slecht voorbeeld voor de andere steden uit te schakelen $\left({ }^{6}\right)$, en wordt eventueel zelfs een bijzondere

(1) A.R.A., R.K., no 42.527, fo 50v-51r (9 sept. 1403) ; no 41.890, fo $26^{\mathrm{r}}$ : ende dat elc sinen lieden soude gheven te kennene.

(2) H.L.St., pp. 136-7, no 375 .

(3) A.R.A., R.K., no 42.527, fo $24^{\mathrm{rv}}$ (29 okt. 1403) : te Brucghe vergadert in de camere van den Vrijen, daer de wetten omboden waeren van den ofzittenden laten ende uut elcken ambachte II of III personen ende desghelike prostlaten, canoniclaten... als omme te hebbene eene subventie... up dwelke de voorseide hemleden berieden ende zeiden dat zij zo aerm waren dat zijs niet ghestaet en waren te ghevene alsup de tijt van nu. Deze procedure was uiteraard erg omslachtig, en het Vrije maakt van dit argument duchtig gebruik om een beslissing te mogen uitstellen (A.D.N., B. $1276, \mathrm{n}^{\circ} 12.987, \mathrm{f}^{\circ} 1^{\mathrm{v}}$ ).

(4) A.R.A., R.K., n० 24.424, fo $26^{\vee}$ (7 juni 1400).

(5) A.D.N., B. 1276, no 12.987 , fo $1^{\mathrm{r}}$ : pour ce que l'on avoit senti que les deputez de la ville d'Yppre vouloient faire tres malgracieuse response et pievre que ceulz des autres villes mon dit seigneur de Nevers parla a eulz a part senz les deputez des autres villes.

(6) Ibid., fo $2^{\mathrm{r}}$ : affin que les diz d'Yppre ne donassent mauvaiz exemple aux autres. 
gezant als bemiddelaar naar deze stad gedelegeerd $\left({ }^{1}\right)$. De steden van hun kant hebben steeds met het argument van armoede, als gevolg van de oorlogsjaren 1379-85, als voorwendsel tot afdingen gemaneuvreerd $\left({ }^{2}\right)$.

De (buitengewone) bede heeft per definitie een volstrekt vrijwillig karakter : de vorst hing dus volledig af van de goede wil der Leden $\left({ }^{3}\right)$. Dit impliceert tevens dat dit college in staat was niet in te gaan op een hertogelijk verzoek en een subsidie radikaal af te wijzen $\left(^{4}\right)$ : voorbeelden zijn inderdaad bekend uit 1389, 1393 (?), 1400 en $1403 . \mathrm{Na}$ weigering door het Leden-college bleef er de vorst niets over dan te pogen elk der Leden afzonderlijk te bewerken $\left(^{5}\right)$. Dergelijke maneuvers in extremis leverden echter nooit enig positief resultaat op.

Het toestaan der beden is de voornaamste basis van de verstrekkende invloed der Leden op de politiek van het graafschap. Het was inderdaad slechts redelijk dat de talrijke subsidies enige tegenpres-

(1) Ibid., fo $1^{\mathrm{r}}$ : le prevost de Bruges et messire Jehan de Pouques furent envoiez audit lieu d'Yppre pour induire et mouvoir ceulz d'Yppre a faire la requeste de mon dit seigneur. Zie ook: A.D.N., B. 18.822, no 23.410 A.

(2) Ibid. : les diz d'Yppre s'excusoient de faire la requeste de monseigneur pour la grand povreté et destrucion de la ville. Zie ook ; A.D.N., B.1276, n 12.974 ; H. LAURENT-F. Quicke, Documents pour servir à l'histoire de la maison de Bourgogne en Brabant et en Limbourg in B.C.R.H., bd. XCVII, 1933, p. 82.

(3) Over het vrijwillig karakter: H. SPANGEnBerg, Vom Lehnstaat zum Ständestaat, Ein Beitrag zur Entstehung der landständischen Verfassung, Hist. Bibl. herausgeg. von der Redaktion der Hist. Zeitschr., bd. 29, München-Berlin, 1912, p. 55 ; М. Вцосн, La société féodale. Les Classes et le gouvernement des hommes, L'Évolution de l'Humanité, bd. XXXIV bis, Paris, 1940, pp. 342-44 ; Pollard, The Evolution, p. 143.

(4) Bv. A.R.A., R.K., no 42.527 , fo $24^{\mathrm{r}}$ en ${ }^{\mathrm{v}}$ : weigering in 1403 . Niet alle Staten konden zich een dergelijke autoritaire houding veroorloven. In Normandië b. v. kende men wel aarzeling, uitstel en voorwaarden, doch geen echte weigering (A. Coville, Les États de Normandie, leurs origines et leur développement au XIV siècle, Paris, 1894, p. 187). Verwerpen van voorstellen was echter wel courant in andere gewesten (J. Billioud, Les États de Bourgogne aux XIV et XV siècles, Acad. des Sc., Arts et Belles-Lettres de Dijon, Dijon, 1922, p. 139 ; A. Dussert, Les États du Dauphiné aux XIVe et XVe siècles, Grenoble, 1915, p. 119).

(5) H.L. St., p. 190, r. 17-20: de graaf van Nevers, die de bede vroeg in naam van zijn vader, besluit te sendene an de IIII Leden personen van sinen rade... daer of an tlant van den Vrijen camen de here van Ghistele en mer Jan van Pouke, die hij hoopte dat se wel informeren soude. 
tatie vanwege de hertog meebrachten. Omtrent de opportuniteit van een aantal maatregelen wordt aldus expliciet geargumenteerd $\left({ }^{1}\right)$. Doch in menig opzicht heeft de financiële steun van het graafschap Filips de Stoute ongetwijfeld tot gematigdheid en inschikkelijkheid aangespoord. Hij is verantwoordelijk voor de goede gezindheid van de vorst tegenover Brugge. Hij verklaart, althans gedeeltelijk, waarom de voorwaarden van de Vrede van Doornik (1385) die als het resultaat van een compromis dient beschouwd, zo gematigd zijn. Hij is een voortdurende stimulans geweest voor de hertog in zijn politiek van economisch herstel na de depressie der oorlogsjaren 1379-1385 ${ }^{2}{ }^{2}$.

Eigenlijke voorwaarden hebben de Leden aan het toekennen der beden niet gekoppeld, voor zover ons bekend is, althans niet in geschreven vorm $\left({ }^{3}\right)$. Wel hebben ze voor elke bede met de vorst of zijn Raad langdurig onderhandeld $\left(^{4}\right)$, en slechts toegegeven na vele aarzelingen $\left({ }^{5}\right)$. Vermoedelijk was dit telkens wel aanleiding voor de Leden om te wijzen op hun bijzondere inschikkelijkheid (ondanks de eigen financiële noden!), en hebben ze voldoende waarborgen weten af te dwingen nopens in het vooruitzicht gestelde tegenprestaties.

In elk geval schiepen deze onderhandelingen voor de Leden een soort Widerstandsrecht, dat, als was het niet in detail uitgewerkt en in juridische vormen gegoten, daarom niet minder invloed op het staatsbeleid heeft gehad. Merken we evenwel op dat, in tegenstelling met andere gewesten $\left({ }^{6}\right)$, het louter betalen in de bede nog geen waarborg

(1) A.R.A., Trés. de Fl., 1 e serie, no 789 (16 april 1396) : Ieper krijgt bijzonder wijnoctrooi verleend door de hertog omdat de stad zich grote inspanningen getroost i.v.m. de bede voor de reis naar Hongarije. Zie ook I. L. A. Diegerick, Inventaire analytique et chronologique des chartes et documents appartenant aux archives de la ville d'Ypres, bd. II, Bruges, 1854, p. 289.

(2) Slechts een gunstige economische conjunctuur kon de stadsfinanciën op een normaal peil houden, hetgeen bijgevolg de vorst opnieuw ten goede kwam.

(3) Voorbeelden van geschreven conditiones zijn bekend in Bourgondië (BILLIoud, États de Bourgogne, p. 142).

(4) Dit was het geval voor alle vazallen van de Franse koning: The only way in which the French king, or one of his great vassals, could secure a general subsidy from all his dependents, was by negotiating with each important individual or group (Stephenson, Taxation, pp. 307-308).

(5) A.D.N., B.1276, no 12.987 ; A.D.N., B.18.222, $\mathrm{n}^{\mathrm{o}} 23.410^{\mathrm{a}}$; of in Normandië: Coville, Etats de Normandie, p. 181.

(6) Stephenson, Taxation, p. 311. 
was voor opname in een representatief standen-college: de kleine steden en kasselrijen die steeds meebetalen werden slechts voor de zetting geconvoceerd, doch overigens volstrekt genegeerd. Anderzijds is het echter wel zo, dat degenen die de bede toestaan, de Leden, ook de teugels der standenvertegenwoordiging in handen hielden, en dus, tenminste voor hen zelf, het devies van het Engelse Magna Chartano taxation without representation - hadden weten te realiseren.

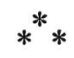

De zetting van de door de Vier Leden toegekende bede was de taak van de vorst en diens ambtenaren $\left(^{1}\right)$. Uiteraard geschiedde de vaststelling der quota echter in nauw overleg met de betrokken betalende partijen.

Een eerste repartitie werd in feite reeds uitgevoerd vóór de toekenning, nl. de verdeling over de standen. De bede van de clerus en die van de Derde Stand werden immers als volstrekt onafhankelijk beschouwd. De standen werden totaal afzonderlijk geconvoceerd en er werd met elk van hen over een verschillend bedrag gediscussieerd.

In princiep waren in de middeleeuwen de geprivilegieerde standen, clerus en adel, van elke belasting vrijgesteld $\left({ }^{2}\right)$. Terwijl in Vlaanderen de adel in algemene zin gespaard bleef, hebben de vorsten er de clerus daarentegen herhaaldelijk om beden verzocht. In de behandelde periode deed de hertog ten minste tweemaal op de geestelijken beroep naar aanleiding van een algemene bede : in $1394\left(^{3}\right)$, onder de bedekte vorm van een zogenaamde lening, en in 1397 ( $\left.^{4}\right)$. De procedure der toekenning komt in aanzienlijke mate met de hoger i.v.m. de Leden geschetste overeen $\left({ }^{5}\right)$.

(1) Cf. in Artesië : Ch. Hirschauer, Les États d'Artois de leurs origines à l'occupation française (1340-1640), bd. I, Paris-Bruxelles, 1923, p. 126.

(2) von Below, Die aelteste Steuer, pp. 632-634.

(3) A.D.N., B. 1276, no 12.974 (discussie op 19 en 20 juli 1394) ; A.R.A., R.K., $\mathrm{n}^{\circ} 16.096, \mathrm{f}^{\circ} 4^{\mathrm{r}-6^{\mathrm{r}}}$ : toestaan van subsidie van 5.275 nobels op 9 aug. 1394 (de vorst had 6.980 nobels gevraagd $\mathrm{l})$.

(4) B.N., Coll. Bourg., no 26, fo $103^{r}$; A.D.N., B. 6761, fo $5^{r} 7^{r}$.

(5) Zie hierover: A.D.N., B.1276, no 12.974. Een uitvoeriger uiteenzetting over de beden van de clerus hopen we eerlang in een andere bijdrage te kunnen leveren. 
De definitieve repartitie binnen elke stand geschiedde echter steeds na de toekenning, al kon dit wel op één zelfde vergadering afgehandeld worden. Om de verdeling der globale som over de steden en de kasselrijen $\left(^{(}\right)$, evenals over de diverse geestelijke instellingen, tot een goed einde te brengen, stelden de hertogelijke ambtenaren reeds bij voorbaat een ontwerp van een repartitie-tabel met vermoedelijke quota op, waarover dan kon onderhandeld worden. Op deze discussies waren, wat de Derde Stand betreft, niet alleen de Vier Leden, doch ook alle (of ongeveer alle) betalende kleine steden en omschrijvingen aanwezig $\left({ }^{2}\right)$. Op een aparte zitting verschenen de gezanten van de abdijen en de kapittels; sterker nog dan de Leden muntten ze uit in het aandringen op vermindering der quota en het formuleren van excuses $\left({ }^{3}\right)$.

Als uitgangspunt voor de omslag werden de quota van het traditionele Transport van Vlaanderen, die nog steeds van kracht waren voor de jaarrente, gebruikt $\left(^{4}\right)$. Op aandringen der Leden werd echter voor elke bede van deze verouderde repartitieschaal afgeweken, en betaalden de steden selon leur faculté. Na de overstroming van 1375-76 en de verwoestingen van de oorlogsjaren 1379-85 beantwoordden deze quota van ca. 1309 allerminst nog aan de werkelijke economische verhoudingen $\left({ }^{5}\right)$. Trouwens ook voor de jaarrente drong zich een

(1) Soms wordt de taxering door de ambtenaren der Rekenkamer pas na de toekenning opgesteld en dan per brief aan elke stad en kasselrij medegedeeld (A.D.N., B.1597, fo 37 r).

(2) A.D.N., B.1276, n 12.974 : nota over de onderhandelingen over de repartitie der kleine steden met de hertogin, de graaf van Nevers en de Raad te Rijsel op 18 juli 1394 ; de enen, zoals de stad Veurne, antwoorden que selon le transport ilz contribueroient volentiers a la somme que Gand, Bruges, Yppre et le terroir du Franc donnaient a monseigneur; anderen, zoals Belle, Poperinge, etc. willen wel storten, doch slechts selon leur faculté (Ibid., fo $1^{\mathrm{r}}$ en $\mathrm{v}$ ). Sommige stadjes achtten discussie blijkbaar overbodig (bv. Lombartsijde en Mardyck) en verschenen dan ook niet op de

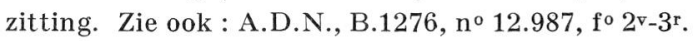

(3) A.D.N., B.1276, no 12.974 , fo $2^{\mathrm{r}-7^{\mathrm{v}}}$.

(4) Bij de repartities wordt immers expliciet vermeld dat ze niet opgemaakt werden selon le transport (A.D.N., B. 1597, fo37r).

(5) In 1394 wordt het afwijken van de transport-quota door de hertog gerechtvaardigd als volgt : tant que pluseurs des dictes villes et lieux de nostre dit pays de Flandres et par les commotions et inundations de la meir qui ont esté en ycelluy, ont esté gastés et destruis, comme pour pluseurs causes (A.R.A., Trés. de Fl., 1 e serie, no 1387). 
herziening op, die plaats vond in $1408\left(^{(1)}\right.$. Voor de beden, die belangrijker sommen betroffen en minder aan traditie waren gebonden, tekenen de sporen zich veel vroeger af. In 1367-68 werd de oude repartitie nog stipt aangewend $\left({ }^{2}\right)$, doch voor de bede van $1377-78$ is men reeds van de normale repartitie van het Transport afgeweken $\left({ }^{3}\right)$. Filips de Stoute heeft dus geen innovatie ingevoerd door dezelfde maatregel tijdens zijn beleid eveneens toe te passen; wel is het een feit dat hij de schaal der bedragen nu systematisch en consequent voor elke bede gaat wijzigen. Voor de subsidie van 1384 was dit normaal vermits de opstand toen nog aan gang was, zodat Gent en enkele andere agglomeraties niet meebetaalden, waaruit dus automatisch nieuwe quota voortvloeiden. Doch ook na de vrede van Doornik, wanneer de toestanden geregulariseerd waren, heeft men voor alle beden wijzigingen in de tabel van het Transport aangebracht $\left({ }^{4}\right)$ : dit is zowel het geval in $1386\left({ }^{5}\right)$, als in $1388\left(^{6}\right)$, in $1394\left(^{7}\right)$ en in $1397\left(^{(8)}\right.$. Eigenlijke vaste regels voor verhogen of verlagen der quota bestonden er in feite niet : ze variëerden van bede tot bede $\left({ }^{9}\right)$. Er is ook geen vergelijking

(1) Gilliodts-van Severen, o. c., bd. IV, pp. 19-27. Reeds op 13 jan. 1395 belastte Filips de Stoute ambtenaren met het onderzoek van de toestand der bevolking met het oog op een eventuele herziening van het transport (E. VANDEN BusSche, Inventaire des archives de l'état à Bruges, Section $1^{\mathrm{re}}$. Franc de Bruges, bd. II, Bruges, 1884, p. 6 ; D. Berten, Coutumes des pays et comté de Flandre, Quartier de Gand, bd. VII, Bruxelles, 1904, pp. 21-22).

(2) Van Werveke, Gentsche Stadsfinanciën, p. 373 ; Gent betaalt in 1367-68: $13.850 \mathrm{lb}$. par. op een totaal van $100.000 \mathrm{lb}$. ; dit is het percentage van het Transport (nl. 13 lb. 17 s. op elke $100 \mathrm{lb}$ ).

(3) ID., p. 373 ; Gent betaalt 8.920 lb. op 74.404 lb., d.i. 11,98\%, d. i. dus bijna $2 \%$ lager dan het Transport.

(4) Men inde dan selonc l'estat et faculté de ville et lieu d'icellui pais et non selonc le transport (A.R.A., Trés. de Fl., 1 e serie, no 1.387; idem: A.D.N., B. 1597, fo $\left.36^{\mathrm{v}}\right)$.

(5) A.D.N., B. 1273, no 11.584 (mei 1386) : een aantal plaatsen zeggen hun deel niet te kunnen betalen, o. m. Gent, Ieper en het Vrije, en krijgen dan ook vermindering toegestaan a grace de monseigneur.

(6) Gilliodts-van Severen, o. c., bd. III, p. 111.

(7) A.D.N., B. 1276, no 13.173.

(8) A.R.A., Trés. de Fl., 1e serie, no 2.490 (4 aug. 1397).

(9) Bijlage I geeft een beeld van de variabiliteit van de quota voor elk der betalende steden en kasselrijen. 
mogelijk tussen de aangepaste repartities bij de diverse beden en het latere gewijzigde Transport van 1408 : voor de subsidies zijn de afwijkingen tegenover de tabel van 1309 veel sterker uitgesproken; het hing eigenlijk af van de welwillendheid, ook wel van de mogelijkheid, van elke stad of gewest op zichzelf. Zo is het duidelijk dat Brugge veel meer betaalt dan nodig was, zelfs rekening gehouden met een zekere aanpassing. Het is bijna steeds zo dat voor de beden het teveel van Brugge het tekort der andere Drie Leden compenseerde, zodat het aandeel der Leden in globo tenslotte toch quasi stabiel bleef $\left(^{(1)}\right.$. Dit wijst tevens op de relatief gestegen welvaart van Brugge ten overstaan van de andere agglomeraties in het graafschap. De stad of districten die een te hoog bedrag stortten, in vergelijking met hun quotum in het transport, lieten zich non-prejuditie brieven toekennen, waardoor de vorst verklaarde de bijzondere gunst niet als een precedent te zullen beschouwen bij een volgende bede $\left({ }^{2}\right)$.

De verdere repartitie binnen elke stad en elke kasselrij wordt niet meer op de algemene centrale vergadering met de hertog of de hertogin voltrokken, doch overgelaten aan plaatselijke instanties. In de steden wordt globaal betaald $\left({ }^{3}\right)$ en is er dus geen verdere verdeling. In de kasselrijen daarentegen worden de quota van elk der parochies $\left({ }^{4}\right)$ en

(1) Een typisch voorbeeld daarvan vinden we bij de bede van 1394 : Gent betaalde toen $9021 / 2$ nobels te weinig, Ieper $2791 / 2$ nobels en het Vrije $1.0501 / 4$ nobels (+ 90 sol. par.) te weinig. Brugge daarentegen stort $2.8471 / 2$ nobels te veel, wat het tekort der eerste drie sommen dus ruimschoots overschrijdt (A.D.N., B.1276, n 13.173).

(2) S.A.B., Stadsrek. 1391-92, fo $73^{\mathrm{v}}$. : aneroerende zekeren lettren die onse gheduchte heere der stede ghaf van dat der stede gheene prejuditie draghen soude van dat de stede van Brugghe nu meer ghaf ter subventie... danne naer den transporte ; Gilliodtsvan Severen, o. c., bd. III, p. 111. Het systeem is ook in Engeland goed bekend (Stephenson, Taxation, p. 307). Zie eveneens: Hirschauer, États d'Artois, bd. I, p. 7 .

(3) Merken we nochtans op dat in enkele kleine steden wel zettingstabellen werden uitgewerkt met de individuele quota voor elk der betalende bewoners. Zie een voorbeeld uit 1399 voor het stadje Eeklo (E. Neelemans, Geschiedenis der stad Eecloo. Verzameling van charters, kronijken, etc., bd. II, Gent-Eeklo, 1865, pp. 171-178). Het is echter niet waarschijnlijk dat deze tabel met een bede verband houdt. Wel is het belangrijk aan te stippen dat de persoonlijke omslag dus ook in kleine steden voorkwam.

(4) Een dergelijke zettingstabel voor al de parochies van de kasselrij Aalst be- 
ondergeschikte ambachten (1) bepaald door bijzondere, door de hertog aangestelde commissarissen, waartoe doorgaans ook de baljuw van het betreffende gebied behoort $\left(^{2}\right)$. Voor de uiteindelijke zetting over de individuele belastingplichtigen in de dorpen stellen deze ambtenaren zich in verbinding met betrouwbare personen, vertrouwd met de economische toestand van de bewoners van elk der localiteiten $\left(^{3}\right)$.

$$
\text { *** }
$$

De heffing tenslotte is eveneens zaak van de vorst. Een bijzondere ontvanger (commis) der bede zorgt voor het centraliseren der sommen in één kas. Plaatselijk zorgen lagere ambtenaren voor de procedure der inning.

Essentieel onderscheid dient gemaakt tussen de steden en het platteland. In de steden wordt het te storten quotum immers globaal door

vindt zich in het A.R.A., Trés. de Fl., $1^{\mathrm{e}}$ serie, no 964 (uit 1394). We hebben deze tekst uitgegeven in het tijdschrift Het Land van Aalst bd. XI, jg. 1959, pp. 260-270. Repartitie over dorpen van Oudburg, volgens Transport van 1309: DE Limburg-Stirum, Codex Dipl., II, pp. 143-44.

(1) Zettingstabellen voor de ambachten en parochies van het Brugse Vrije : A.R.A., R.K., no 42.521 tot 42.528 , telkens fo1 ${ }^{\mathrm{r}}$ en vlg. (jaren 1395-1405).

(2) A.R.A., Trés. de Fl., $1^{\mathrm{e}}$ serie, $\mathrm{n}^{\circ} 964$ (1394) : C'est l'assiete du tax et percion du terroir d'Alost des appartenances de l'aide... faite par le bailli de le conté d'Alost Clais Utenhove, Renier Kempe et Gille de Waesberghe, commissaires a ce ordonnéz par mon dit seigneur, par la moniere qu'il s'ensuit. Lijst van de commissarissen der bede van 1397 voor elk der kasselrijen van Vlaanderen : A.D.N., B. 1277, n $^{0}$ 13.690 ; telkens komt de baljuw voor naast één tot drie andere personen; deze ambtenaren werden aangeduid door de kanselier en de Raad. Reeds vóór de Bourgondische periode speelden de baljuws een rol in de organisatie der belastingen (H. Nowé, Les baillis comtaux de Flandre des origines à la fin du XIV e siècle, Mém. Acad. Roy. De Belg., Cl. Des Lettres, 2 e série, bd. XXV, Bruxelles, 1928, pp. 216-7).

(3) A.R.A, Trés. de Fl., $1^{\mathrm{e}}$ serie, $\mathrm{n}^{\circ} 2.490$ (4 aug. 1397) : et en oultre substitués et commettés de par vous bonnes personnes prudemmes et ydoines a ce en chascune desdictes villes et paroisses dudit terroir pour asseoir justement et raisonnablement sur les manans et habitans d'icelles et autres quî avecque euls vivent et sont accoustumés de contribuer en tel fait (J. Frorssart, Chroniques (1325-1400), éd. Kervyn de Lettenhove, bd. XXII, Bruxelles, 1875, p. 286). In de keuze van die geschikte personen werden de commissarissen totaal vrijgelaten : commetons... que appelle avec vous ceux que bon vous samblera de la dicte ville et terroyer de Warneton (A.R.A., Trés. de Fl., 1 e serie, n 1387). 
de magistraat uit de stadskas geput en aan de centrale ontvanger overgemaakt $\left(^{1}\right)$; het nodige geld daartoe wordt hoofdzakelijk verzameld d.m.v. ongelden en andere taksen op verbruiksgoederen $\left({ }^{2}\right)$; de belasting trof bijgevolg de gehele bevolking zonder onderscheid, en zelfs in de eerste plaats de minder gegoeden.

Op het platteland worden de vastgestelde sommen geïnd door speciale vorstelijke ontvangers, pointers of hoofdpointers genoemd $\left(^{3}\right)$.

De controle op de heffing wordt uitgeoefend door de genoemde bijzondere ontvanger en rekenmeester, aangesteld door de hertog als commis voor de bede $\left({ }^{4}\right)$. Aan deze ambtenaar werden door de vorst de

(1) De uitgaven voor de beden staan in de rekeningen der steden steeds globaal bij de uitgaven genoteerd, ook in de kleine steden (A.R.A., R.K., no 36.391 , Rek. Monikerede 1394-95, fo $2^{\mathrm{r}}$; Id., no 34.537 , Rek. Veurne 1396-97, fo $19^{\mathrm{r}}$; Id., no 33.149, Rek. Kortrijk 1395-96, fo $14^{\mathrm{r}}$; Id., no 33,545 , Rek. Damme 1394-95, fo $3^{\mathrm{v}}$. De term komt vnl. in de kasselrij Kortrijk voor (A.D.N., B.1277, n 13.690). In de rekeningen van het Brugse Vrije staan eveneens globale stortingen aan de hertog vermeld; ze werden echter opgebracht door verzameling van gelden in de ambachten en parochies, zoals blijkt uit de rubriek der ontvangsten (bv. A.R.A., R.K., no 42.522, fo $1^{\mathrm{r}}$ ). Eeklo bv. betaalt als stadje zijn aandeel globaal aan de ontvanger van het Vrije (Id., no 34.359, Rek. Eeklo, 1409-10, fo 2v).

(2) J. Craeybeckx, De Staten van Vlaanderen en de gewestelijke financiën in de $X V I \mathrm{I}$ eeuw. Het verzet tegen Alva's Tiende Penning in Hand. v. d. Mij. voor Gesch. en Oudheidk. te Gent, bd. IV, Nieuwe reeks, 1949-50, pp. 83-84 ; ID., Aperçu sur l'histoire des, impôts en Flandre et en Brabant au cours du XVI $I^{\mathrm{e}}$ siècle in Revue du Nord, bd. XXIX, 1947, pp. 90-91. De betaling der steden geschiedde vaak d.m.v. wisselbrieven, een operatie waartoe ze zich telkens gewend hebben als hun fondsen niet toereikend waren (G. BIGwood, Le régime juridique et économique du commerce de l'argent dans la Belgique du Moyen Age, Acad. Roy. De Belg, Cl. Des Lett., Mém., bd. I, Bruxelles, 1921, pp. 124-125). Ten onrechte beweert Bigwood echter dat die wisselbrieven werden verdisconteerd. Zoals R. de Roover (L'évolution de la lettre de change, $X I V^{\mathrm{e}}-X V I I I^{\mathrm{e}}$ siècles, Paris, 1953, pp. 32 en 34 ) aantoonde, kwam disconto van wisselbrieven in de middeleeuwen niet voor. Het bedrag dat door de financiers werd afgehouden voor de wissels die ze bezorgden was geen disconto, maar een courtage. We danken Prof. H. Van Werveke die ons op dit aspect attent maakte.

(3) Craeybeckx, De Staten van Vlaanderen, p. 83.

(4) In 1394 was dit bv. de raadsheer Pieter van der Tanerie; deze is gehouden een register aan te leggen met de volledige boekhouding (inkomsten en uitgaven) der bede. Dit document is thans bewaard in het A.R.A., R.K., n 16.096. In 1397 werd van der Tanerie opnieuw met deze opdracht gelast; zijn verslagboek is thans : A.D.N., B. 6.761. 
nodige volmachten gedelegeerd, die hem toelaten weigerige stadsbesturen tot betalen te dwingen $\left(^{1}\right)$.

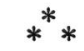

Filips de Stoute heeft, van 1384 tot 1403, 10 algemene beden aangevraagd, waarvan er 6 werden toegekend; bovendien werd één particuliere bede verleend door het Land van Aalst. In het hiernavolgend overzicht der beden werden de voornaamste gegevens nopens elk dezer subsidies (datering, bedrag, motief en eventuele moeilijkheden bij de vereffening) gegroepeerd.

De eerste bede - eigenlijk veeleer een verplichte belasting - dateert van 10 mei 1384. Filips had op die dag aan de meeste localiteiten en omschrijvingen van Vlaanderen (buiten Gent en andere verder rebellerende steden) genade verleend en algemene kwijtschelding uitgevaardigd $\left({ }^{2}\right)$, en knoopte aan deze grootmoedige concessie onmiddellijk de voorwaarde vast dat al die plaatsen hem maandelijks een speciale oorlogsbelasting zouden toekennen tot het ogenblik van de definitieve onderwerping van Gent, Oudenaarde en hun aanhangers $\left({ }^{3}\right)$. De bedoeling was deze subsidie met grote nauwgezetheid te innen : de eerste termijn werd op 31 mei 1384 vastgesteld $\left(^{4}\right)$; de laatste bleek tenslotte op 31 december 1385 te vallen — dus enkele dagen na de ondertekening van de Vrede van Doornik - zodat twintig betalingen hadden moeten plaats vinden $\left(^{5}\right)$. Theoretisch moest Filips

(1) Et vous donnons plain pooir, auctorité et mandement especial de lever, cuellir, exploitier et recevoir yceuls aydes et de constraindre ou faire constraindre ad ce par toutes voyes et manieres deues (A.R.A., R.K., no 16.096, fo $1^{\mathrm{v}}$ ).

(2) A.D.N., B.1273, Trés. des Chartes, no 11.381 (10 mei 1384) : Comme naguaires les... habitans de notre pays de Flandres... se sont des dittes choses du tout en tout soubmise et mise en notre voulenté... nous aux dessus dittes villes et habitans nos bons et vrays subgets quittons et pardonnons toutes offances.

(3) A.D.N., B.1273, $\mathrm{n}^{0}$ 11.381. Zie ook: Froissart, Chroniques, bd. X, éd. Kervyn de Lettenhove, p. 543 (met fouten); M. Gachard, Rapport à Monsieur le ministre de l'intérieur sur différentes séries de documents concernant l'Histoire de Belgique, qui sont conservées dans les Archives de l'ancienne chambre des comptes de Flandre à Lille, Bruxelles, 1841, p. 67 .

(4) Et sera le premier payement de ce present assise"en la fin de ce present mois [= mei] et les autres à la fin de chacun mois (A.D.N., B. 1273, n 11.381).

(5) Dit blijki uit een optekening van de termijnen voor Brugge : les quelz il 
elke maand $13.965 \mathrm{~F}$ innen of in totaal $279.300 \mathrm{~F}\left({ }^{1}\right)$. In werkelijkheid zijn de innigen niet met zoveel stiptheid geschied en hebben heel wat steden het "volle pond" niet betaald $\left({ }^{2}\right)$. De repartitie zag er uit als volgt :

\begin{tabular}{|c|c|c|c|}
\hline \multirow[b]{2}{*}{ Brugse Vrije } & \multirow{2}{*}{$\begin{array}{l}\text { Gevraagde } \\
\text { sommen } \\
\text { per maand }\end{array}$} & \multicolumn{2}{|c|}{ Betaald van mei 1384 tot juni 1385} \\
\hline & & 1.089 lb. 19s. & par $\left({ }^{3}\right)$ \\
\hline Brugge & $3.000 \mathrm{Fr}$. & 37.429 lb. $12 \mathrm{~s}$. & par. \\
\hline Veurne (stad + kass.) & $1.500 \mathrm{Fr}$. & $5.596 \mathrm{lb}$. & par. + 105 Fr. \\
\hline Kortrijk (stad + kass.) & $1.200 \mathrm{Fr}$. & Nihil & \\
\hline Sluis & $1.200 \mathrm{Fr}$. & Nihil & \\
\hline Ieper & $1.000 \mathrm{Fr}$. & Nihil & \\
\hline St. Winoksbergen (stad+kass.) & $450 \mathrm{Fr}$. & $920 \mathrm{lb}$. & par. \\
\hline Kassel (stad + kass.) & $450 \mathrm{Fr}$. & $1.527 \mathrm{lb} .9 \mathrm{~s}$. & par. \\
\hline Damme & $375 \mathrm{Fr}$. & $3.068 \mathrm{lb}$. & par. \\
\hline Ieper (kass.) & $300 \mathrm{Fr}$. & $800 \mathrm{lb}$. & par. \\
\hline Poperinge & $250 \mathrm{Fr}$. & Nihil & \\
\hline Bailleul (stad + kass.) & $150 \mathrm{Fr}$. & $800 \mathrm{lb}$. & par. \\
\hline Duinkerken & $100 \mathrm{Fr}$. & Nihil & \\
\hline Broekburg (stad + kass.) & $100 \mathrm{Fr}$. & Nihil. & \\
\hline Waasten (stad + kass.) & $60 \mathrm{Fr}$. & $100 \mathrm{lb}$. & par. \\
\hline Nieuwpoort & $50 \mathrm{Fr}$. & Nihil & \\
\hline Lo & $20 \mathrm{Fr}$. & - & $20 \mathrm{Fr}$. \\
\hline Lombartsijde & $10 \mathrm{Fr}$ & - & $10 \mathrm{Fr}$. \\
\hline Totaal & $\begin{array}{l}13.965 \mathrm{Fr} . \\
\text { (zie noot 1) }\end{array}$ & $\begin{array}{r}51.559 \mathrm{lb} \text { par. }+ \\
\text { (zie }\end{array}$ & $\begin{array}{l}+135 \mathrm{Fr} . \\
\text { noot } 2 \text { ) }\end{array}$ \\
\hline
\end{tabular}

doivent de $X X$ mois, escheus le derrenier jour du mois de decembre derrenierement passé (Gilliodts-van Severen, o. c., bd. III, p. 85).

(1) Het maandelijkse totaal bekomt men door samentelling van de sommen vermeld in A.D.N., B. 1273, $\mathrm{n}^{\circ}$ 11.381, het algemene totaal door vermenigvuldiging van dit bedrag met 20 (aantal termijnen).

(2) Op 26 jan. 1386 had Brugge voor deze bede tot dan toe slechts 18.714,75 Fr. betaald, terwijl de stad in feite 60.000 Fr. $(3.000 \times 20)$ schuldig was (Gilliodtsvan Severen, o. c., bd. III, p. 85); de schuld is trouwens nooit helemaal afgelost, vermits op 31 jan. 1386 de hertog een belangrijke kwijtschelding op het achterstallig bedrag toestond (Ibid., p. 86). Uit de rekening van $\mathbf{H}$. Lippin, ontvanger van Vlaanderen (A. D. N., B. 4073, fo $34^{\mathrm{v}}-36^{\mathrm{r}}$ ) blijkt dat de eerste 14 maanden $51.559 \mathrm{lb}$. en $135 \mathrm{Fr}$. werd gestort. Er werd dus zeker $51.329 \mathrm{lb}$. $+135 \mathrm{Fr}$. $=27.271,31 \mathrm{Fr}$., betaald, d.i. een tekort van $252.028,69 \mathrm{Fr}$. Het bleek niet mogelijk te achterhalen hoeveel precies later nog aan achterstallige sommen betaald werd. Zeker is dat nog enkele stortingen geschiedden (zie hoger in deze voetnoot i.v.m. Brugge).

(3) Het Vrije betaalde bovendien $120 \mathrm{lb}$. voor Oostende en $108 \mathrm{lb}$. voor Oudenburg. 
In 1386 stond de hertog voor de absolute onmogelijkheid de kosten van de verdediging van de Vlaamse kuststrook met normale inkomsten te bestrijden. Op 12 april had hij de kapiteins en krijgslieden te Duinkerken, Biervliet, Nieuwpoort en andere kuststeden, er van op de hoogte gebracht dat ze weldra hun achterstallige soldij zouden ontvangen dank zij een bede die in het vooruitzicht gesteld was $\left({ }^{1}\right)$. Op 10 mei werd deze inderdaad te Gent door de Leden toegestaan $\left({ }^{2}\right)$. In de maanden mei en juni zouden telkens $6.000 \mathrm{~F}$. geïnd worden, dus in totaal $12.000 \mathrm{~F}$. of $25.200 \mathrm{lb}$. par. $\left(^{3}\right)$; daar een aantal plaatsen hun deel niet wilden of konden betalen, heeft Filips tenslotte vermoedelijk slechts $21.894 \mathrm{lb} .12 \mathrm{~s}$. par. ontvangen $\left({ }^{4}\right)$, dus een tekort van 3.305lb. 8s. of $1.574 \mathrm{~F}$. Aan de vastgestelde termijn had men zich evenmin gehouden, vermits de Leden op 13 juli 1386, dus reeds veertien dagen na verlopen van de termijn een verontschuldigingsbrief ter zake aan de hertog richten $\left(^{5}\right)$. De moeilijkheden der inning dient men ongetwijfeld toe te schrijven aan de erbarmelijke financiële en economische toestand waarin het graafschap na het einde van de opstand verkeerde $\left(^{6}\right)$.

In 1388 werd een bede aangevraagd met het oog op de oorlog van de Bourgondische hertog tegen Gelre. Ze was veel aanzienlijker dan de vorige, bedroeg in totaal 100.000 gouden franken ( $\left.{ }^{7}\right)$, en werd toege-

(1) A.D.N., B.1273, no 18.808 (12 april 1386).

(2) De juiste datering konden we slechts door combinatie van verschillende bronnen bereiken. Uit A.D.N., B. 1273, $\mathrm{n}^{\circ}$ 11.584, blijkt dat de Leden de bede te Gent aan de Raad van de hertog toestonden in mei 1386. Volgens de Brugse rekeningen zijn de Bruggelingen slechts éénmaal in deze maand naar Gent gereisd, nl. op 10 mei 1386 (S.A.B., Stadsrek. 1385-86, fo 105v). De rekeningen van het Vrije gewagen, gezien het motief der bede van tglavieghelt (H.L.St., p. 6, r. 16 en 27).

(3) H.L.St., p. 7, r. 1-3. De bede was a tailler de II mois seulement.

(4) Inkomsten van deze bede genoteerd in drie opeenvolgende rekeningen van de ontvanger van Vlaanderen : A.D.N., B.4075, fo 45 r (16.391 lb. 16s.). Id., B. 4076, fo $36^{\mathrm{r}}$ en $37^{\mathrm{v}}$ (2.040 lb.) ; Id., B.4077, fo $35^{\mathrm{v}}$ (3.462 lb. 16s.). Later is geen spoor van betaling meer te vinden, en er is ook geen sprake van optekening in een schulden-register, zoals bij andere beden wel eens gebeurde.

(5) H.L.St., p. 9, r. 1-2.

(6) Froissart, Chroniques, bd. XIII, éd. Kervyn de Lettenhove, pp. 374-375 signaleert Kervyn, zonder verwijzing, dat de hertog in 1387 klaagt over het niet betalen der bede.

(7) A.D.N., B. 4077, fo $30^{\mathrm{r}}-33^{\mathrm{\sigma}}$. 
staan te Atrecht op 22 febr. 1388. Het aandeel van Brugge werd reeds op 25 juni 1388 betaald $\left({ }^{1}\right)$. Deze stad was er voor verplicht een belangrijke lening aan te gaan bij een aantal notabelen uit de stad $\left({ }^{2}\right)$, die dan als vergoeding en waarborg het beschikkingsrecht verkregen over al de assisen van de stad $\left(^{3}\right)$.

Een poging in april 1389 tot afdwingen van een buitengewone toelage van $1.000 \mathrm{lb}$. gro., door de hertog, mislukte zeer vermoedelijk. Behalve van de aanvraag $\left({ }^{4}\right)$, is er immers verder geen spoor van terug te vinden.

Het doel waarvoor de hertog in augustus $1391\left(^{5}\right)$ een bede van 60.000 nobels aanvroeg $\left({ }^{6}\right)$ is ons niet bekend $\left({ }^{7}\right)$. Ze werd tenslotte in september te Argilly toegekend, na verlaging tot 45.000 nobels $\left({ }^{8}\right)$. De betaling bracht talrijke moeilijkheden mee $\left({ }^{9}\right)$; slechts na herhaald

(1) S.A.B., Charter no 695 en 699 (22 febr. 1388 ; 25 juni 1388) (Gilliodts-vaN Severen, o. c., bd. III, pp. 111 en 124). Over de vergadering te Atrecht ; H. L. St., p. 21, no $^{\circ} 2 \mathrm{e}$.

(2) Gilliodts-van Severen, o. $c$., bd. III, p. 112. Voor de toestemming daarin vanwege de hertog, zie : A.R.A., Trés. de Fl., $1^{\mathrm{e}}$ serie, ${ }^{\circ} 555$ en A.D.N., B. 1597, fo $11^{\text {r }}$. (13 juni 1388).

(3) A.D.N., B. 1597 , fo $16^{\mathrm{v}}$; B. 1347 , no 11.734 (12 mei 1388).

(4) H.L.St., p. 30, no $77 \mathrm{e}$ (7 apr. 1389) ; vermoedelijk ook : p. 30, n० $78 \mathrm{~b}(20$ apr. 1389).

(5) H.L.St., p. 65, n 180b (20 aug. 1391) ; J. H. VAN Dale, De oudste stadsrekening van Sluis, in : H. Q. JANssen en J.H. VAN DALE, Bijdragen tot de oudheidk. en gesch., inz. v. Zeeuwsch-Vl., bd. IV, Middelburg, 1859, p. 23.

(6) H.L.St., p. 66, r. 35-6 ; A.R.A., R.K., no 41.890 (Rek. Kass. Oudenaarde), fo $26^{\mathrm{r}}$.

(7) A.D.N., B.1597, fo 37r wordt enkel vermeld : pour certaines et justes causes.

(8) Dit is ons bekend uit een stuk van latere datum: A.D.N., B. 1597, fo $36^{\mathrm{v}}$. (26 febr. 1392). We weten trouwens dat een gezantschap der Leden op 18 sept. 1391 naar Argilly vertrok, waar de bede werd toegestaan (H. L. St., p. 68, no 186b).

(9) Er waren drie termijnen voorzien : Quasimodo [ = 21 april] 1392, H. Remigius [= 1okt.] en kerstdag 1392 (A.D.N., B. 1597, fo 37r). De vermelding van een bede van 5.000 nobels toegestaan in sept. 1391 volgens de rekening van J. van Streyhem, ontvanger van Biervliet en Harelbeke (A.R.A., R.K., nº 6890, Rek. 1387-94, fo $14^{v}$ ) betreft ongetwijfeld een verschrijving voor de hier besproken belasting van 45.000 nobels. Zie voor de drie opeenvolgende betalingen van Brugge in deze bede bij Gilliodts-van Severen, o. c., bd. III, p. 192 (7 april 1392, n. s.), p. 223 (30 april 1392), en p. 253 ( 8 jan. 1393). Wegens allerlei moeilijkheden diende de zaak in januari 1392 opnieuw door de Leden besproken (H.L.St., p. 76, r. 31). Aanvankelijk werden slechts kleine bijdragen gestort, en het is pas na een uitspraak van de hertogelijke Raad op 26 febr. 1392 (A.D.N., B.1597, fo $36^{v}$ ), dat de betalingen regel- 
uitstellen der termijnen, geraakte de zaak in 1393 van de baan ${ }^{1}$ ).

Op 31 maart 1393 wordt op een Leden-parlement te Gent gediscussieerd over een taxatie op het land van $9.000 \mathrm{lb}$. par. $\left({ }^{2}\right)$. Behalve deze laconieke vermelding is nopens deze zeer waarschijnlijk nooit toegekende subsidie geen enkel gegeven voorhanden.

De financiering van de kruistocht tegen de Turken, onder leiding van de oudste zoon van de hertog, was aanleiding tot het verzoek om een bede van 100.000 nobels $\left({ }^{3}\right)$, op 11 juni 1394 door de hertog tot de Leden gericht $\left({ }^{4}\right)$. Vooraleer deze hun toestemming gaven, volgde eerst een langdurige discussie over de totale som en over de repartitie der bijdragen $\left(^{5}\right)$; zowel de Leden $\left(^{6}\right)$ als de kleine steden en kasselrijen $\left(^{7}\right)$ kwamen in juli 1394 erover onderhandelen met de hertogin. In augustus 1394 werd men het, vermoedelijk te Gent $\left({ }^{8}\right)$, eens voor een bedrag van 65.000 nobels $\left({ }^{9}\right)$. De eerste termijn werd bepaald op 2 febr.

matig en aanzienlijk werden (zie ook : H.L.St., pp. 81-82, $\mathrm{n}^{\circ} 255$ ). Derde en laatste storting in deze bede door Kortrijk (stad) op 15 jan. 1393 (A.R.A., R.K., nº 33.147, fo $^{\mathrm{v}}$ ), door Geraardsbergen op 7 jan. 1393 (Id., $\mathrm{n}^{\circ} 35.231$, fo $17^{\mathrm{v}}$ ).

(1) Allusie uit 1393 op moeilijkheden bij de stortingen; K.B., Hs. Cab., Coll. Mergh., n $32-\mathrm{II}$, p. 158 : omme te impetreren huutset van mijns heren ghelde twelke men hem sculdich was (1 $\mathrm{e}$ kw. 1393).

(2) H.L.St., p. 93, r. 26-27.

(3) Zie ook: H. DAvid, Philippe le Hardi, duc de Bourgogne et co-régent de France de 1392 à 1404. Le train somptuaire d'un grand Valois, Dijon, 1947, pp. 3536. Zie A.D.N., B. 18.822 , p. $164, \mathrm{n}^{\circ} 23.258$ (aan de clerus waren 10.000 nobels gevraagd).

(4) H.L.St., pp. 100-101 (n० 283).

(5) Id., p. 101, r. 3. Zie ook: Id., p. 101, no 284 (19 juni 1394). Zie vooral : Laurent-Quicke, Documents, pp. 81-82, 93-94, 98, 100, 108 en 114.

(6) A.D.N., B.1276, $\mathrm{n}^{\circ}$ 13.173. Het stuk is ongedateerd maar ongetwijfeld van kort vóór 18 juli 1394, gezien de datum van het document in de volgende voetnoot geciteerd. Zie ook : H.L.St., p. 103 n $^{\circ} 291$ b en c ; p. 104, nº 292.

(7) A.D.N., B.1276, no 12.974 (op 18 juli 1394) : hun tussenkomst betreft echter uitsluitend de repartitie der bijdragen; over het totale bedrag beslissen de Leden immers autonoom. Zie ook: H.L.St., pp. 103-4, no 291.

(8) H.L.St., p. 105, nº 295 (28 aug. 1394).

(9) A.R.A., R.K., $\mathrm{n}^{\circ} 16.096$, fo $1^{\mathrm{r}}$. Dit document geeft op fo $1^{\mathrm{v}-\mathrm{f}^{\circ}} 3^{\mathrm{v}}$ de verdere repartitie der sommen over de verschillende steden en kasselrijen. Over het afdingen zie : H.L.St., p. 104, r. 25-6. Men mag het akkoord voor 65.000 als een persoonlijk succes van de hertogin beschouwen, die enerzijds het overdreven hertogelijk verzoek van 100.000 nobels moet temperen, en anderzijds toch meer kon afdwingen 
1395 ; de tweede zou door een latere ordonnantie vastgesteld worden $\left(^{1}\right)$. In september 1394 gaf de hertog bevel tot de verdere repartitie der sommen in de diverse omschrijvingen over te gaan $\left(^{2}\right)$. De tweede termijn werd gesteld op 24 juni 1395, maar wegens vertraging in de organisatie van de tocht, naderhand tot 1 oktober 1395 verschoven $\left({ }^{3}\right)$. In feite werd zelfs nog in april 1396 een achterstallig bedrag voor deze bede betaald $\left({ }^{4}\right)$.

In oktober 1396 werd een bede geïnd die vermoedelijk een particulier karakter droeg. Gegevens zijn inderdaad slechts voorhanden voor het Land van Aalst en Geraardsbergen. Deze kasselrij stortte op die datum een totaal bedrag van $4.000 \mathrm{~F}$, pour l'avancement des ouvrages des chasteaux et maisons de Flandres ${ }^{5}$ ).

De kruistocht tegen de Turken, of liever de mislukking van de kruistocht na de slag van Nicopolis, leidde tot een nieuwe bede in 1397, bestemd om als losgeld te dienen voor de personaliteiten die tijdens de tocht naar Hongarije door de ongelovigen gevangen genomen waren $\left({ }^{6}\right)$.

dan haar raadgevers gehoopt hadden (deze laatsten wilden immers afdalen tot 50.000 ) en dan wat de Leden zelf aangeboden hadden, nl. 40.000 (Billioud, États de Bourgogne, p. 90). Over de taktiek der hertogin zie ook haar brief aan Filips op 31 aug. 1394 ; A.D.N., B.18.822, no $23.280^{\text {a }}$.

(1) A.D.N., B.1276, no 12.988 (aug. 1394): toestemmingsacte der Leden. Zie ook : Id., no 13.172.

(2) A.R.A., Trés. de Fl., $1^{\text {e }}$ serie, n 1387 : op 17 sept. 1394 wordt de verdere repartitie voor Waasten bevolen. Brugge betaalde in verschillende stortingen voor de eerste termijn (nl. op 26 nov. en 15 dec. 1394 ; en op 17 maart 1395) (Gilliodtsvan Severen, o. c., bd. III, p. 346).

(3) A.D.N., B.18.822, p. 192, n 23.300 : mandament van 14 mei 1395 verschuift de datum van de tweede termijn.

(4) S.A.B., Charter no 791 en no 811 (respectievelijk op 7 dec. 1395 en 7 april 1396) (Gilliodts-van Severen, o. c., bd. III, p. 345 en p. 357) : twee stortingen van bijdragen in deze bede door de stad Brugge. Betalingen in de rekening van 1396-97 eveneens in Veurne (A.R.A., R.K., n $^{\circ} 34.537$, fo 19 r), en Kortrijk (Id., $\mathrm{n}^{\circ} 33.150$, fo $^{13 \mathrm{v}}$ ).

(5) De bede werd ontvangen door Clais Scaec, baljuw van het graafschap Aalst; het hertogelijk verzoek was overgemaakt door souverein-baljuw, de heer van Leeuwerghem, en ontvanger-generaal Pieter van der Tanerie (A.R.A., R.K., nº 48.835, fo $1^{r}$ ). De inning bracht $7.358 \mathrm{lb} .2 \mathrm{~s}$. par. op (Ibid., fo $6^{\mathrm{r}}$ ).

(6) Over de rol van de Italiaanse financier Dino Rapondi bij het verzamelen der nodige sommen voor dit losgeld, zie L. Mirot, La société des Raponde, Études Lucquoises, Bibl. de l'Ec. des Chartes, bd. LXXXIX, 1928, pp. 356-362; en GiL- 
Zeer waarschijnlijk werd het verzoek door de hertog aan de Leden voorgelegd in begin april 1397 tijdens hun reis naar Senlis $\left(^{1}\right)$. Oorspronkelijk vroeg de vorst niet minder dan 150.000 nobels $\left({ }^{2}\right)$, doch de Vlamingen wisten het, na langdurige discussies $\left({ }^{3}\right)$, tot 100.000 nobels te herleiden, som die op 13 juli 1397 werd toegestaan $\left({ }^{4}\right)$. De betaling zou in drie termijnen geschieden, waarvan de eerste bepaald werd op kerstdag $1397\left({ }^{5}\right)$. Zowel voor het Vrije $\left({ }^{6}\right)$, als voor Brugge $\left({ }^{7}\right)$ werd de eerste bijdrage vóór de voorziene datum geïnd. De hertog had immers op spoed aangedrongen, gezien het dringende karakter van de kwestie $\left.{ }^{(}\right)$. De laatste bijdrage werd eveneens (voor Brugge althans) lang vóór de vervaldag uitbetaald $\left({ }^{9}\right)$.

In 1400 verzocht de hertog de Leden nogmaals om een subsidie, om het laatste deel van het losgeld dat hij voor het vrijkopen van zijn oudste zoon, de graaf van Nevers, aan de Turken schuldig was, te kunnen afbetalen. Op 22 mei 1400 ontbood deze laatste de Leden te Rijsel om van hen een subsidie van 30.000 nobels los te krijgen $\left({ }^{10}\right)$. De gezanten van de steden en het Vrije leggen de zaak aan hun respectievelijke schepenbanken voor; te Gent wordt ze speciaal besproken

Liodts-van Severen, o. c., bd. III, pp. 285-286 ; B. N., Coll. Bourg., no 26, fo $103^{\text {r }}$; no 101, fo $86^{\mathrm{v}}$.

(1) H.L.St., p. 136, n 374b : de Leden vertrokken op 31 maart 1397 naar Senlis. Het doel is in deze post niet uitgedrukt. Bij hun terugkeer blijkt echter dat het ongetwijfeld over de bede ging (H. L. St., p. 136, nº 375).

(2) Het oorspronkelijke verzoek van 150.000 nobels blijkt uit : H.L.St., p. 136, r. 24-25.

(3) H.L.St., pp. 136-141, no ${ }_{2} 375-384$ (op 24 april, 8 mei, 13 mei, 16 mei, 16 juni, $2^{\text {e }}$ kw. $1397 ; 27$ juni, 3 juli en 13 juli 1397).

(4) H.L.St., p. 140-141, no 384 (13 juli 1397).

(5) A.R.A., Trés. de Fl., 1 serie, no 2.490 (4 aug. 1397).

(6) A.R.A., R.K., $\mathrm{n}^{\circ} 42.522$, fo $1^{\mathrm{r}}$ : het Vrije betaalt zijn eerste aandeel op 6 okt. 1397.

(7) S.A.B., Stadsrek. 1397-98, fo $51^{\mathrm{v}}$ : Brugge doet de eerste storting (1/3 van haar aandeel) op 22 okt. 1397.

(8) A.R.A., Trés. de Fl., 1e serie, no 2.212 (4 aug. 1397) (i.v.m. Kortrijk).

(9) De laatste termijn was bepaald op 2 febr. 1399. Brugge betaalde de laatste bijdrage op 7 april 1398, dus 10 maanden bij voorbaat (Gilliodts-van Severen, o. c., bd. III, p. 288). Ook het Vrije betaalde volledig zijn aandeel uit (A.R.A., R.K., $n^{\circ} 42.523$, fo $4^{v}$, datum echter niet aangegeven).

(10) H.L.St., p. 189, r. 12-13. 
in de Grote Collatie en door de diverse neringen ( ${ }^{1}$ ). Op 7 juni 1400 gaat men te Rijsel de graaf mededelen de bede niet te kunnen toestaan ( $\left.{ }^{2}\right)$. Ondanks diens protest, en zijn pogingen om de Leden afzonderlijk te bewerken, wordt men het tenslotte toch niet eens $\left(^{3}\right)$. De opgegeven reden der weigering is ons niet bekend. In elk geval konden de Leden doen gelden dat zij reeds in 1397 voor dezelfde zaak een ruime toelage van 100.000 nobels toegekend hadden.

Op 9 sept. 1403 tenslotte stelde Filips de Stoute aan de Leden voor hem een subsidie van niet minder dan 120.000 nobels toe te staan $\left(^{4}\right)$. De Vlamingen hebben het verzoek druk op hun parlementen besproken ${ }^{5}$ ). Maar vermits uit de laatste vergadering niet blijkt dat men tot een accoord gekomen is, en vermits de rekeningen naderhand geen uitgaven voor een bede vermelden, mogen we aannemen dat de Leden de hertog een ongunstig advies hebben medegedeeld. We weten trouwens dat de voornaamste belastingbetalers in het Vrije, ter informatie samengeroepen op 29 oktober 1403, onverzettelijk weigerden tot een eventuele subsidie bij te dragen $\left(^{6}\right)$.

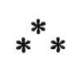

Traditioneel gaf de hertog bij zijn verzoek telkens] nauwkeurig het doel aan, waarvoor de gevraagde sommen bestemd waren. Als motieven kwamen bijna alleen militaire argumenten in aanmerking $\left(^{7}\right)$ : in 1384 met het oog op het liquideren van de Vlaamse opstand van $1379-85\left(^{8}\right)$; in 1386 , voor de soldij van garnizoenen die de kusten van het graafschap moeten beschermen $\left({ }^{9}\right)$; in 1388 voor de oorlog die

(1) Id., p. 189, r. 29-31. (29 mei 1400).

(2) Id., p. 190, no 485.

(3) H.L.St., p. 191, r. 14 (27 juni 1400) : upt nieuwe ontsecghen der 30.000 noblen.

(4) Id., p. 282, r. 1.

(5) Id., pp. 282-291, n 630-641, op 29 sept. ; 6, 7, 19 en 28 okt.; op 12 en 21 nov. 1403.

(6) A.R.A., R.K., no 42.527 , fo $24^{\mathrm{r}}$ en $\mathrm{v}$.

(7) Dit verschijnsel schijnt universeel te zijn (StePhenson, Taxation, p. 307).

(8) A.R.A., Trés. de Fl., $1^{\text {e }}$ serie, $n^{\circ} 2.460$ (10 mei 1384) : de Vlaamse steden en kasselrijen moeten maandelijks een vast bedrag betalen totdat de opstand volledig beëindigd is.

(9) A.D.N., B. 1273, no 11.584 (mei 1386) : à cause des gens d'armes, arbalestiers, pikenars, ordinés sour la frontiere de la mer. 
Filips, als bondgenoot van Johanna van Brabant, tegen de hertog van Gelre voerde $\left(^{1}\right)$; in 1394 om de krijgsexpeditie tegen de Turken, die Hongarije binnengevallen waren, financieel mogelijk te maken $\left({ }^{2}\right)$; in 1397 om de voornaamste personaliteiten die tijdens deze tocht door de vijand gevangen genomen waren weer los te kopen $\left({ }^{3}\right)$; in 1400 voor hetzelfde doel $\left(^{4}\right)$. In zekere zin zou men enkele der geciteerde gevallen kunnen beschouwen als verwant met de groep der klassieke quatre cas féodaux $\left(^{5}\right)$ : nl. de kruistocht in $1394\left(^{6}\right)$ en de losprijs voor de gevangen troonopvolger in 1397 en $1400\left(^{7}\right)$. Voor de beden van 1391 en 1403 is de voorgestelde bestemming niet te achterhalen.

De vraag is of de door de vorst geïnde sommen ook wel degelijk door hem tot het aangegeven doel werden aangewend. Controle hadden

(1) A.R.A., Trés. de Fl., $1^{\mathrm{e}}$ serie, $\mathrm{n}^{\circ} 555$ (13 juni 1388) : une subvencion de cent mille franx, en ayde de mener nostre guerre contre le duc de Ghelre, qui sans cause nous a deffié.

(2) A.D.N., B.18.822, p. 192 (14 mei 1395) : pour le fait de l'aide a nous ottroyé pour cause de nostre voyage de Hongrie, lequel nous entendions a faire en ceste presente saison. In de aanvraag wordt tevens gespeculeerd op het religieuze gevoel der bevoling : voyage... pour la defence de la chrestienneté nous entendons a faire a la nouvelle saison devers les marches de Hungrie a l'encontre des Sarrasins qui de pieca sont entrez ou dit pays de Hungrie et ailleurs pour destruire nostre foy (A.R.A., R.K., $\mathrm{n}^{\circ}$ 16.096, fo $1^{\mathrm{r}}$ ).

(3) S.A.B., Charter, no 848 (3 febr. 1398): pour la redemption et delivrance de mons. le conte de Nevers son aisne filz liquels estoit detenus prisonniers en le main des Turs ennemis de foy christienne.

(4) A.R.A., R.K., no 42.526, fo $26^{\mathrm{r}}$ (22 mei 1400).

(5) Er bestaat nopens deze klassieke gevallen nogal wat verwarring. In het middeleeuwse Duitsland kende men er doorgaans drie : gevangenschap van de vorst, huwelijk van zoon of dochter, ridderslag van oudste zoon (von BELow, Die aelteste Steuer, pp. 657-658); soms komt een vierde voor, nl. noodtoestand van het territorium (SPANGENBERG, Vom Lehnstaat, p. 54). In Frankrijk is het vierde geval doorgaans het kruistochtmotief of eventueel het aankopen van land door de vorst (F. L. Ganshof, Qu'est-ce que la féodalité, Bruxelles, 1957, p. 123 ; Bloch, La Société féodale. La Formation, pp. 343-344). Nopens de effectieve toepassing in Franse gewesten, zie Billioud, États de Bourgogne, p. 114; Hirschauer, Etats d'Artois, bd. I, p. 3.

(6) Reeds als dusdanig beschouwd door David, Philippe le Hardi (Le train somptuaire), p. 36.

(7) Het feodaal motief werd eveneens uitgespeeld in de bede geheven in 1399 in Waals-Vlaanderen, vcor een bedrag van 2.500 nobels, naar aanleiding nl. van het tot ridder verheffen van Jan, graaf van Nevers (A.D.N., B.1598, fo 116 ). 
de Leden daarop niet, vermits vorstelijke en staatsfinanciën elkaar volkomen dekten, en de hertog dus naar willekeur over zijn fiscale inkomsten, ongeacht hun oorsprong, beschikken kon $\left({ }^{1}\right)$. Uit een staat, die als een soort budget voor persoonlijk gebruik van de hertog kan beschouwd worden, met inkomsten en uitgaven van de beden van 1394 in al zijn bezittingen ( ${ }^{2}$ ), blijkt dat deze veruit het overgrote deel der sommen werkelijk voor het voorgestelde doel voorbestemt. Meer bepaald worden in $1394400.000 \mathrm{~F}$. gereserveerd voor de kruistocht naar Hongarije ; de resterende sommen worden aangewend als dotatie (gewone uitgaven, klederen, onderhoud van kastelen) van de hertogin (44.400 F.), voor de bouw van defensiewerken te Sluis (10.000 F.); voor aankoop van grond voor de Kartuizers te Dijon (6.000 F.), voor de veneurs van de hertog ( $3.000 \mathrm{~F}$.), voor herstelwerken aan hertogelijke residenties $(6.000 \mathrm{~F}$.), voor pensioenen aan leden van het hôtel van de hertog (22.000 F.), tenslotte nog $27.000 \mathrm{~F}$ waarmee de vorst vrij zijn schulden vereffenen mag.

$$
*^{*} *
$$

De betekenis der beden, door het graafschap Vlaanderen aan de hertog toegestaan, kan gemeten worden aan de druk op de stedelijke budgetten. Ondanks de rampspoedige gevolgen van de binnenlandse conflicten was het graafschap een ongemeen rijke bron van inkomsten gebleven, hetgeen niet naliet op de contemporaine kroniekschrijvers een zeer sterke indruk te maken $\left(^{3}\right)$. De sommen die de Vlaamse steden

(1) Craeybeckx, De Staten van Vlaanderen, p. 80. Pas na 1543 krijgen de Vlaamse Staten het recht na te gaan of de bedragen wel worden aangewend voor de doeleinden, waarvoor ze waren toegestaan (J. DHond, Bijdrage tot de kennis van het financiewezen der Staten van Vlaanderen in Nederl. Historiebladen, bd. III, 194041, p. 159).

(2) A.D.N., B.1277, no 13.109. Een zelfde indruk wekt het register met de werkelijke uitgaven van de bede voor Vlaanderen in 1394 : van de totale ontvangen som van $276.542 \mathrm{lb} .10 \mathrm{~s}$. 6d. par., worden vermoedelijk $193.902 \mathrm{lb} .15 \mathrm{~s}$. gereserveerd voor het aangegeven doel (de kruistocht naar Hongarije) ; $1.650 \mathrm{lb}$. is bestemd voor de uitgaven van de hertogin ; $46.426 \mathrm{lb}$. 10s. voor aankoop van gronden en kastelen in Overmaas en Limburg ; giften en remissies bedragen in totaal $2.313 \mathrm{lb}$.; schadeposten van niet geïnde achterstellen : 5.672 lb. (A.R.A., R.K., no 16.096 , fo $7^{r_{-}}$ $11^{\mathrm{v})}$.

(3) Tekenend is volgende passus uit Froissart, Chroniques, bd. XVI, éd. Ker- 
en gewesten hem jaarlijks toekenden, onder vorm van vaste betalingen, beden en andere stortingen, vormden een uiterst zware post in de rekeningen van die agglomeraties: in Brugge kwam het in sommige schepenjaren voor dat $2 / 3$ van de inkomsten van de stad in de kas van de hertogelijke ontvanger-generaal overgeheveld werden ${ }^{1}$ ). Deze herhaalde aderlatingen der stadsfinanciën betekenden ongetwijfeld een drukkende last en een onbetwistbare opoffering $\left({ }^{2}\right)$ : om de nodige gelden te kunnen verzamelen hebben de magistraten niet geaarzeld hun toevlucht te nemen tot leningen $\left({ }^{3}\right)$, tot het trekken van wissels $\left({ }^{4}\right)$ en het heffen van supplementaire ongelden $\left(^{5}\right)$.

\section{$*^{*} *$}

vyn de Lettenhove, pp. 58-59 (oktober 1397) i.v.m. de losprijs voor de gevangenen in Hongarije : et par especial ceulx de Flandres, ou il redonde et habonde moult de finances pour le fait de la marchandise, en eussent la greigneur part et taxation. Zie ook (i.v.m. de bede voor de organisatie van de tocht): Istore et chroniques de Flandre, bd. II, éd. Kervyn de Lettenhove, C.R.H., Bruxelles, 1880, p. 414 : lequel pays (Flandres) luy fist grand confort et aide, tant de finanche comme de gens d'armes. Zie verder nog J. Brandon, Chronodromon avec les additions d'Adrien de Budt, Chron. rel. à l'hist. de Belg. sous les ducs de Bourg., éd. Kervyn de Lettenhove, bd. I, C.R.H., Bruxelles, 1870, p. 24.

(1) Gilliodts-van Severen (o.c., bd. III, p. 113) heeft uitgerekend dat $\pm 2 / 3$ van het gemiddeld budget van de stad Brugge in handen van de hertog kwamen (nl. 62.617 lb. 9s. par. op \pm 100.000 lb. par.). In 1357 ging 2/5 naar de graaf (L. VANDERkindere, Le siècle des Artevelde, Bruxelles, 1907, p. 184).

(2) V. Fris, Dagboek van Gent van 1447 tot 1470 , bd. I, Gent, 1901, p. 61 : in 1447 erkent de hertog dat de beden in Vlaanderen oorzaak waren van de uitputting van het land (zo huut ghemolcken).

(3) Brugge gaat in 1388 een lening aan bij een aantal notabelen van de stad,

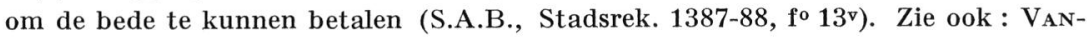
DERKINDERE, Le siècle des Artevelde, p. 184.

(4) Voor de bede van 1397 (voor de gevangenen van de kruistocht) verschafte Brugge zich de nodige fondsen d.m.v. verschillende wisselbrieven (zie S.A.B., Stadsrek. 1397-98, fo $49 \mathrm{v}$ en fo $50^{\mathrm{r}}$ ).

(5) Dit was het geval te Gent, waar in 1401-02 een vrij zwaar bijzonder ongeld werd ingevoerd van $12 \mathrm{~s}$. gro. op elk vaatje wijn, naast de twee reeds bestaande van 5s. en 3s. gro. In 1401-02 brachten de ongelden samen 127 lb. 4d. gro. op (S.A.G., 400 (11), fo 17r); deze assisen vormden niet minder dan $73 \%$ der totale inkomsten (in 1401-02 nl. 1281 lb. 3s. gro. op 1742 lb. 8s. 8d. gro., cf. Ibid., fo 17v en 20₹). In 1404-05 kon Gent er toe overgaan dit supplementaire ongeld van 12s. gro. te laten vallen (S.A.G., 400 (11), fo 63r); er werden toen immers geen beden meer toegestaan. 
In het kader van de financiën der Bourgondische hertogen, waarvoor thans een vrij grote belangstelling schijnt te bestaan, speelden de beden een aanzienlijke rol. Het ware bijgevolg wenselijk dat deze bescheiden bijdrage over de periode 1384-1404 aanleiding mocht geven tot uitwerking in de tijd, nl. over de opvolgers van Filips de Stoute, en tot het afwegen van de betekenis der beden in Vlaanderen tegen die der andere bezittingen van deze hertogen. In meer algemene zin zou ook de preciese omvang van de betekenis der Nederlanden voor de totale fiscaliteit van het Bourgondisch landencomplex op punt moeten gesteld worden (1).

W. Prevenier

\section{BiJlage I}

\section{Variatie-tabel van de quota der Vlaamse steden en kasselrijen in de beden van 1384-1404}

In dit overzicht werden opgenomen de quota der Vlaamse steden en kasselrijen van alle beden waarvoor deze gegevens voorhanden waren, met name die van 1386, 1388, 1391, 1394 en 1397. Tevens werden vermeld : de Transport-schaal van 1309 en die van 1408, daar zij interessante vergelijkingen mogelijk maken tussen de repartitie van de buitengewone met die van de vaste belastingen.

Voor elke bede geven we voor elke localiteit het werkelijk bedrag, dat door de hertogelijke ambtenaren ervoor werd vastgesteld in de omslagtabellen; tevens berekenden we wat deze som procentueel betekent tegenover het totale bedrag der bede. De plaatsen werden gerangschikt in dalende orde volgens de quota der oudste tabel (die van 1309).

In de kolom van 1386 worden enkele sommen aangeduid met de vermelding NB (= niet betaald). Deze localiteiten hebben hun aandeel inderdaad nooit gestort in de kas van de ontvanger-generaal.

In enkele repartitie-documenten werden de quota van enkele agglomeraties uit het Land van Waas afzonderlijk genoteerd. Omwille van de uniformiteit hebben we deze bedragen eenvoudig geïncorporeerd in de totale som voor deze kasselrij. Toch geven we de specificatie van deze plaatsen in een aparte tabel.

Het belang van deze repartitie-tabellen ligt hierin dat ze als vergelijkingsmateriaal kunnen dienen met de latere haardtellingen, die in Vlaan-

(1) Voorlopige constataties in Mollat, Recherches sur les finanees, p. 309 e.v. 
deren voorkomen sedert $1469\left(^{1}\right)$, om de fiscale en economische belangrijkheid der localiteiten tegen elkaar af te wegen. Ze geven een inzicht in de verhoudingen voor een periode waarin deze haardtellingen nog niet voorhanden zijn, althans voor de grote en kleine steden en kasselrijen. Wat de smaldelinghen over de dorpen betreft kan de evolutie van de $\mathrm{xIV}^{\mathrm{e}}$ naar de $\mathrm{Xv}^{\mathrm{e}}$ eeuw uitstekend nagegaan worden door vergelijking der gedetailleerde repartitie-tabellen van $1394(2)$ en $\left.1408 \overline{(2}^{2}\right)$ met de tellingen van 1469.

\section{TABELlEN OPGESTELD OP BASIS VAN VOLGENDE DOCUMENTEN}

1309 Th. De Limburg-Stirum, Codex Diplomaticus Flandriae, II, Brugge, 1889, pp. 141-143, nº 253.

L. Gilliodts-van Severen, Inventaire ville de Bruges, bd. IV, Brugge, 1876, pp. 279-80.

1386 Algemene tabel : A.D.N., B.1273, no 11.584 (repartitietabel opgesteld na een aantal kwijtscheldingen door de hertog).

1388 Algemene tabel : A.D.N., B. 4077, fo $30^{r}$ - $33^{\text {p }}$.

1391 Algemene tabel : A.D.N., B.1597, fo $37^{\text {r }}$.

1394 Algemene tabel : A.D.N., B. 1276, nº 12.988.

A.D.N., B.1276, no 13.172 .

A.R.A., R.K., $\mathrm{n}^{\circ} 16.096$, fo $1^{\mathrm{v}}-3^{\mathrm{r}}$.

Aandeel kasselrij Kassel : A.D.N., B.490, no 21.128 ; B.18.822, p. 179, $n^{\circ}$ 23.282 .

Aandeel Waasten : A.R.A., Trés. de Fl., $1^{\circ}$ s., nº 1387.

1397 Algemene tabel : A.D.N., B. 6761, fo $1^{\mathrm{r}}-3^{\mathrm{v}}$.

1408 Gilliodts-van Severen, o.c., IV, pp. 23-27; Stadsarchief Gent, Serie 93bis, $\mathrm{n}^{\circ} 1$, Witteboek, fo $162^{\mathrm{v}}-163^{\mathrm{r}}$.

(1) A.D.N., B.195, no 14, 15, 24, 25, 28, 31 ; B.196. Zie Jos. De Smet, Le dénombrement des foyers en Flandre en 1469, B.C.R.H., bd. XCIX, 1935, pp. 105-150.

(2) A.R.A., Trés. de Fl., 1e serie, n 964 (Land van Aalst.)

(2) Stadsarchief Gent, Reg. 93 bis, no 1 , Wittenboek, fo 163 ${ }^{\mathrm{v}}$ (Oudburg), $164^{\mathrm{r}}$ (Nevele), 164 ${ }^{\mathrm{r}-165^{\mathrm{r}}}$ (Vier Ambachten), 165 ${ }^{\mathrm{r}}$ en ${ }^{\mathrm{v}}$ (Land v. Waas), 166 ${ }^{\mathrm{r}}-167^{\mathrm{v}}$ (Land van Aalst, 167v-168v (kasselrij Kortrijk), 168 $8^{\mathrm{v}}-169^{\mathrm{r}}$ (kass. Oudenaarde), 169 $9^{\mathrm{rv}}$. (Land van Dendermonde): telkens lijst met quota die de dorpen in deze omschrijvingen betalen op elke $1.000 \mathrm{lb}$. belasting in het Transport van Vlaanderen. Zie ook: de Limburg-Stirum, Codex Dipl., II, pp. 143-44. 


\begin{tabular}{|c|c|c|c|c|c|}
\hline & & 1388 & 1391 & 1394 & 1397 \\
\hline Aarschot $\left({ }^{1}\right)$ & 7 & F 6 s. 9 d. & $11 \mathrm{lb} .15 \mathrm{~s}$. & $17 \mathrm{lb} .12$ s. $6 \mathrm{~d}$. & 7 nob. \\
\hline Beveren & 263,5 & F 10 s. 6 d. & $420 \mathrm{lb}$. & $630 \mathrm{lb} .-\quad-$ & 302 nob. \\
\hline Burcht & 70 & F 17 s. 6 d. & $116 \mathrm{lb} .-$ & $174 \mathrm{lb} .-\quad-$ & 84 nob. \\
\hline Coudenburg ( $\left.{ }^{2}\right)$ & 59 & F 13 s. 6 d. & $99 \mathrm{lb} .-$ & $128 \mathrm{lb} .10 \mathrm{~s}$. & 61 nob. \\
\hline Exaarde & 60,5 & F 4 s. - & $113 \mathrm{lb} .-$ & $169 \mathrm{lb} .10 \mathrm{~s} .-$ & 81 nob. \\
\hline Haasdonk & 87 & F 17 s. 6 d. & $145 \mathrm{lb} .-$ & 217 lb. 10 s. - & 100 nob. \\
\hline Kruibeke & 182 & F 5 s. $8 \mathrm{~d}$. & $300 \mathrm{lb} .-$ & $450 \mathrm{lb} .--$ & 217 nob. \\
\hline Massemen ( $\left.{ }^{3}\right)$ & 21,5 & F 7 s. - & $35 \mathrm{lb} .-$ & $52 \mathrm{lb} .10 \mathrm{~s} .-$ & 27 nob. \\
\hline Pumbeke $\left({ }^{4}\right)$ & 17 & F 7 s. 4 d. & $28 \mathrm{lb} .10 \mathrm{~s}$. & 42 lb. 15 s. - & 18 nob. \\
\hline Rupelmonde & 57 & F 7 s. 3 d. & $95 \mathrm{lb} .-$ & 142 lb. $10 \mathrm{s.}-$ & 110 nob. \\
\hline Sint-Niklaas & 43,5 & $\mathrm{~F}-\quad-$ & $72 \mathrm{lb} .12 \mathrm{~s}$. & 108 lb. 18 s. - & 57 nob. \\
\hline Temse & 235 & F 15 s 3 d. & $380 \mathrm{lb} .-$ & 570 lb. - - - & 273 nob. \\
\hline Zottegem ( $\left.{ }^{5}\right)$ & 5 & F 4 s. 4 d. & $8 \mathrm{lb} .10 \mathrm{~s}$. & $12 \mathrm{lb} .15 \mathrm{~s} .-$ & 5 nob. \\
\hline
\end{tabular}

Deze sommen zijn reeds begrepen in de totalen van de algemene tabellen.

\section{BiJlage II}

\section{Globaal overzicht der Vlaamse beden 1384-1404}

In de hiernavolgende tabellen wordt, op basis van de documenten vermeld in dit artikel (in paragraaf : overzicht der beden) en in de inleiding tot bijlage I, een synoptische tabel gegeven van : 1) de door de vorst gevraagde sommen ; 2) de na discussie op de parlementen door de Leden aan de vorst toegestane bedragen; 3) de werkelijk getaxeerde sommen (som der werkelijke quota na de zetting). De toegestane sommen, onder 2, vormden slechts een basis voor de repartitie; lichte afwijkingen (naar boven of naar onder) waren nadien echter nog mogelijk

(1) Aarschot: heerlijkheid onder Sint-Niklaas (enclave van Belsele).

(2) Coudenborch: kasteel te Temse.

(3) Massemen, normaliter bij het Land van Aalst gerekend (A.R.A., Trés. de Fl., $1^{\mathrm{e}}$ serie, $\mathrm{n}^{\circ} 964$ ), doch wordt in de tabellen fiscaal in het Land van Waas geïncorporeerd.

(4) Pumbeke : heerlijkheid onder Sint-Niklaas (enclave van Belsele).

(5) Bedoeld is hier een heerlijkheid van de heer van Zottegem te Haasdonk (volgens : Stadsarchief Gent, 93bis. nº 1 , Witteboek, fo $175^{\vee}$ ). 
daar bij de repartitie bepaalde steden en omschrijvingen op de oorspronkelijk voorziene quota nog een deel meenden te moeten afdingen, of omgekeerd tot een iets hogere bijdrage bereid bleken; het totaal van deze laatste sommen (onder 3) vormt dus de reëel toegestane bede.

Op de vraag of alles wat toegestaan was ook effectief aan de vorst betaald werd is het zeer moeilijk precies te antwoorden. Vele steden betaalden op zeer uiteenlopende tijdstippen en buiten de voorziene termijnen. Hun stortingen staan dan op de meest onverwachte plaatsen der rekeningen van de ontvanger-generaal genoteerd. Wat erger is : niet alle registers zijn bewaard gebleven. Volledige controle der betalingen is dus uitgesloten. Het probleem schijnt echter groter dan het vermoedelijk is. In praktisch alle gevallen immers mag men aannemen dat de getaxeerde sommen uiteindelijk toch betaald worden, zij het dan in verschillende en uiteenliggende stortingen $\left(^{1}\right)$. Slechts voor de bede van 1384 en 1386 is het bepaald zeker dat een aanzienlijk percentage der toegestane sommen nooit gestort werden. In 1384 was er vermoedelijk een tekort van $252.028,69 \mathrm{~F}\left(^{2}\right)$; in 1386 van $1.574 \mathrm{~F} .\left(^{3}\right)$.

Werkelijk betaald totaal bedrag der beden onder Filips de Stoute is dus waarschijnlijk :

$861.967,51 \mathrm{~F}$ (werkelijk getaxeerde som)

$-253.602,69 \mathrm{~F}$ (tekorten of kwijtscheldingen)

$=608.364,82 \mathrm{~F}$

In feite zou men ook de beden van de Vlaamse clerus in rekening kunnen brengen. In 1394 betaalde deze $18.990 \mathrm{lb}$. par. of $11.509,09 \mathrm{~F} .\left(^{4}\right)$; in $1397: 25.898$ lb. 8 s. par. of 15.696 F. $\left({ }^{5}\right)$. Het algemeen totaal zou dus worden :

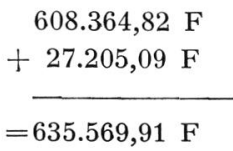

(1) De ontvangers der beden noteren in hun rekeningen bij niet of bij niet integraal betalen in margine van de post over de betreffende stad de opmerking: Il est mis ou livre des debtes (A.R.A., R.K., nº 47.046, fo 43). Doorgaans kan men de nagekomen stortingen in de volgende rekeningen repereren.

(2) Dit tekort is een maximum. Het is immers zeker dat van de gevraagde $279.300 \mathrm{~F}$ er $27.271,31 \mathrm{~F}$ werd gestort. Vermoedelijk werd iets meer betaald, doch de preciese omvang kon niet achterhaald worden.

(3) Referenties hoger in het overzicht der beden onder 1384 en 1386.

(4) A.R.A., R.K., n० 16.096, f० 6 r.

(5) A.D.N., B. 6761, fo $7^{\mathrm{r}}$. 
In de synoptische tabellen worden de sommen telkens weergegeven : 1) in de munt waarin het verzoek van de hertog uitgedrukt wordt ; 2) in Vlaamse ponden parisis ; 3 ) in franken $\left({ }^{1}\right)$. De bonte verscheidenheid van gangbare en in de rekeningen door elkaar aangewende munten, maken het inderdaad wenselijk alle sommen tot één standaardmunt te herleiden. Slechts op die wijze is onderlinge vergelijking en het berekenen van een algemeen totaal mogelijk. Het omrekenen in lb. par. en franken stelde een aantal problemen als gevolg van de sterke wisselvalligheid der koersen $\left({ }^{2}\right)$.

Koers van de frank in lb. par. (vlaamse munt).

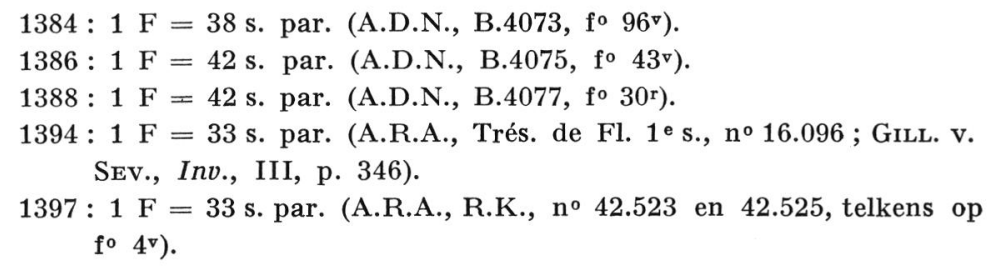

Koers van de nobel, van 1391-1403, steeds :

1 nobel $=72$ s. par. (vlaamse munt) (A.D.N., B. 1276, n $^{\circ} 12.988$; A.D.N., B. 6761, f $^{\circ} 6^{\nabla}$; Gilliodts-van Severen, Inv., III, pp. 259,346).

(1) De lb. par. werd gekozen als courante Vlaamse munt, meest gebruikt in de rekeningen van steden en kasselrijen. De frank als munt van de centrale administratie, meer bepaald van de ontvanger van alle finantiën. Deze sommen in franken uitgedrukt kunnen dus zeer goed met de beden in andere gewesten (Bourgondië, etc.) vergeleken worden. Ze sluiten aan bij de unificatie doorgevoerd door Mollat (zie formulering van wens tot unificatie en overzicht van de moeilijkheden bij omrekening der talrijke Bourgondische munten: Mollat, Recherches sur les finances, pp. 298-299) en talrijke andere specialisten in de Bourgondische financiën : 1 frank stemt immers overeen met $1 \mathrm{lb}$. tournois, franse (bourgondische) rekenmunt. Zie : Arch. Dép. Côte d'Or, Dijon, B. 1461 , fo $172^{\mathrm{r}}$; B. 1467 , fo $86^{\mathrm{v}}$; B. 1500 , fo $185^{\mathrm{v}}$; telkens is werhouding : 1 frank $=20 \mathrm{~s}$. tourn. (frans) en 1 frank $=16 \mathrm{~s}$. par. (frans).

(2) We stellen er bijzonder prijs op hier Prof. H. Van Werveke, promotor van onze licentiaatsverhandeling, zeer hartelijk dank te zeggen voor de grote bereidwilligheid waarmee hij onze moeilijkheden met deze monetaire problemen wilde oplossen, en ons een uitvoerige nota over het probleem der koersschommelingen ter beschikking heeft gesteld. 
DE BEDEN IN HET GRAAFSCHAP VLAANDEREN (1384-1404) 365

\begin{tabular}{|c|c|c|c|}
\hline \multirow{3}{*}{ 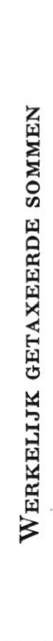 } & 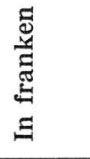 & 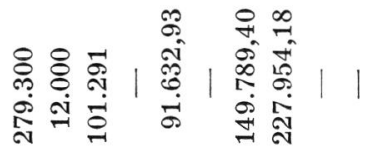 & 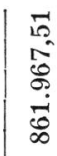 \\
\hline & $\stackrel{\dot{\Xi}}{\Xi}$ & 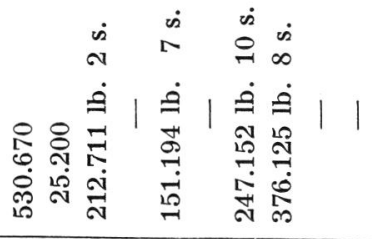 & 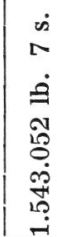 \\
\hline & 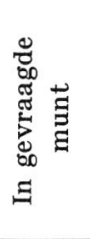 & 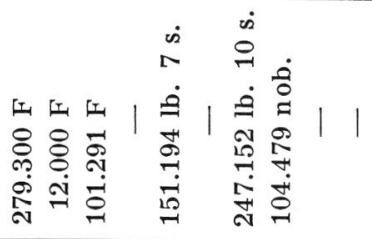 & \\
\hline \multirow{3}{*}{ 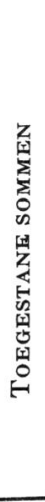 } & 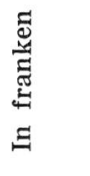 & 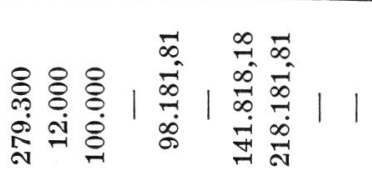 & 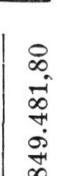 \\
\hline & $\begin{array}{l}\dot{\Xi} \\
\Xi \\
\Xi\end{array}$ & 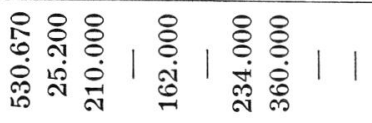 & 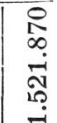 \\
\hline & 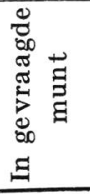 & 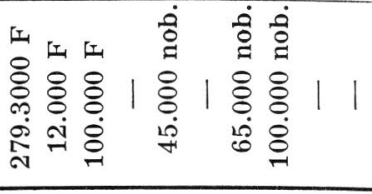 & \\
\hline \multirow{3}{*}{ 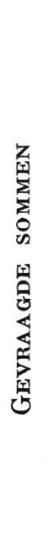 } & 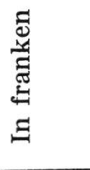 & 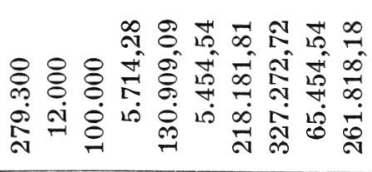 & 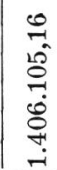 \\
\hline & 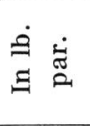 & 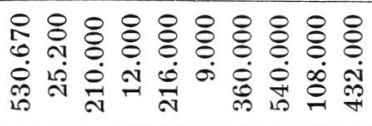 & 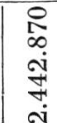 \\
\hline & 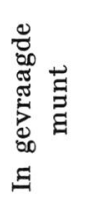 & 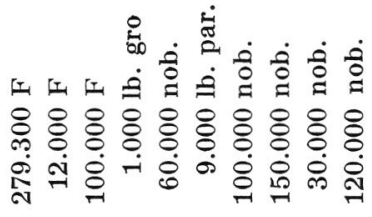 & \\
\hline & & 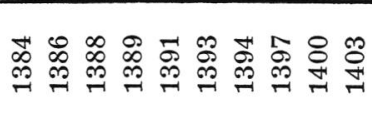 & 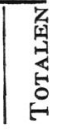 \\
\hline
\end{tabular}




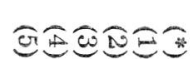

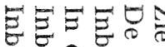

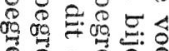

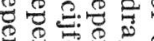

을

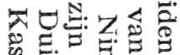

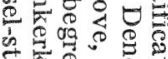

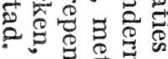

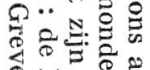

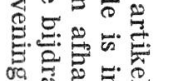

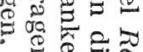

政

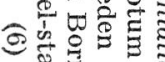

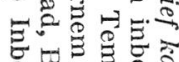

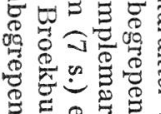

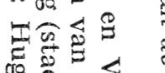

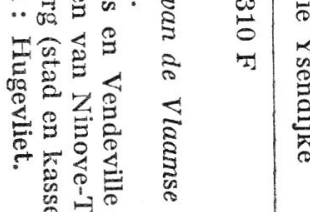

官

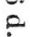

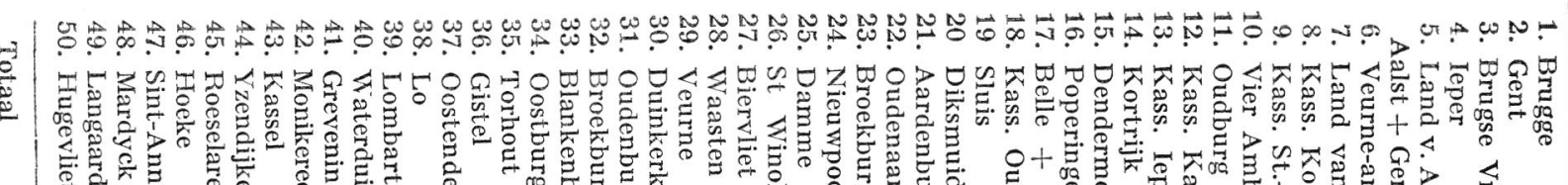

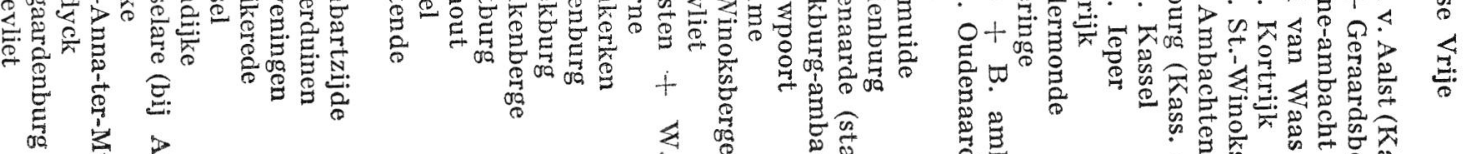

量

爵

惫

要

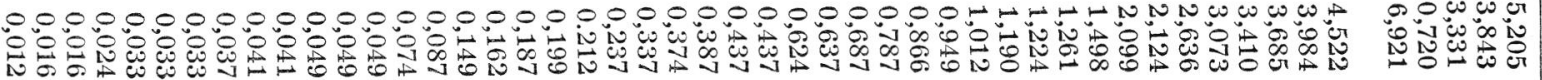

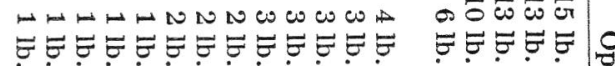

1

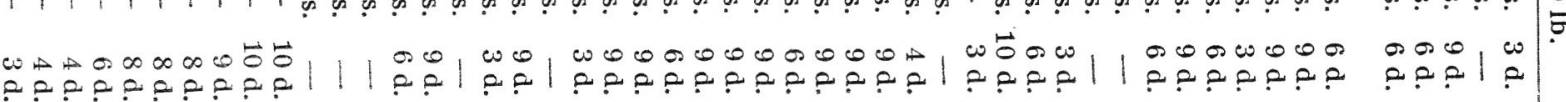

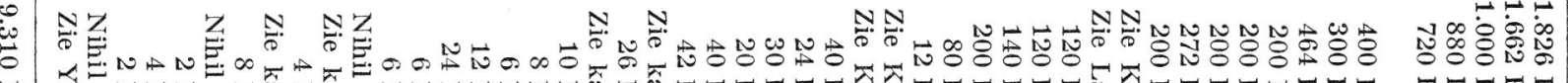

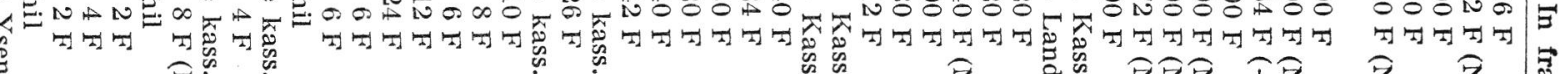

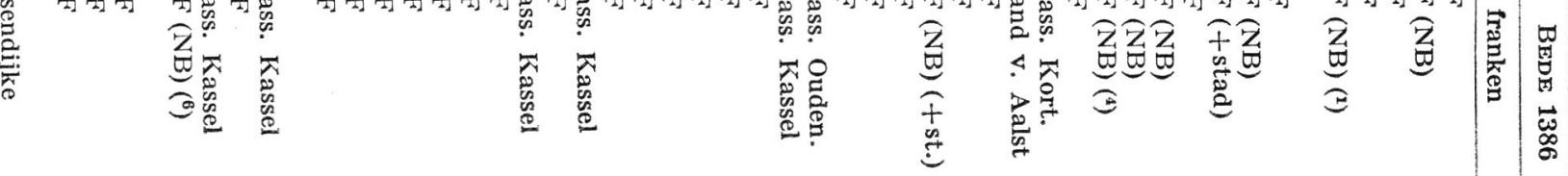

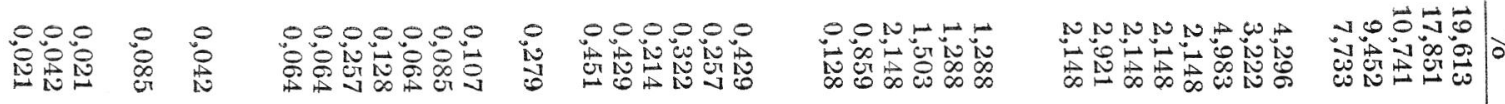

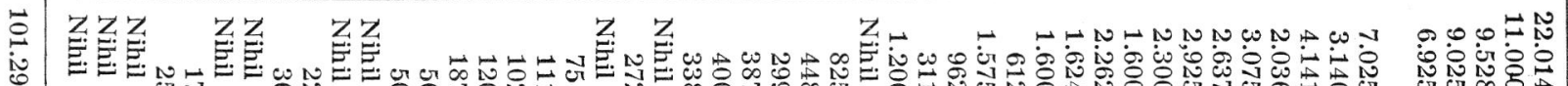

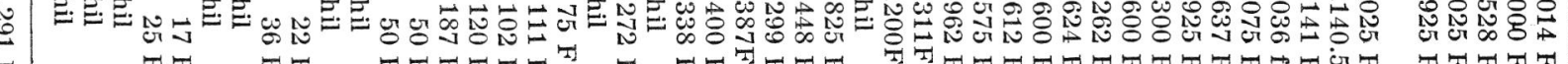

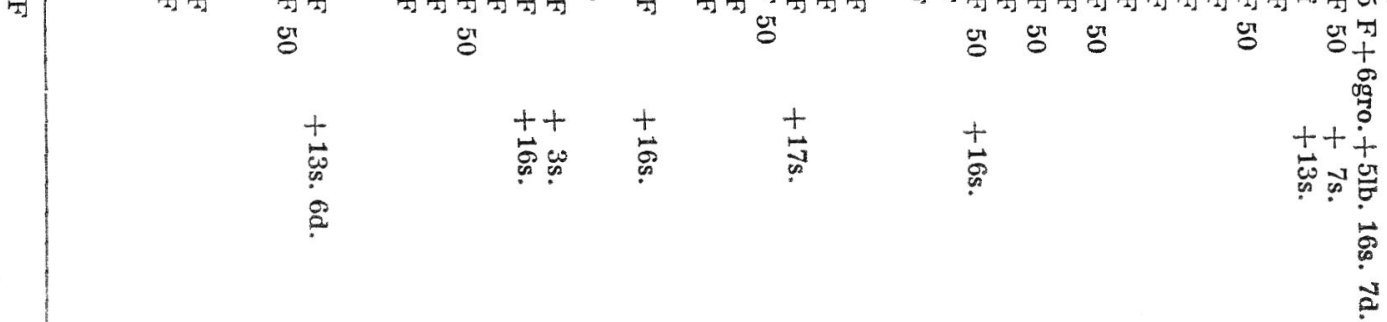

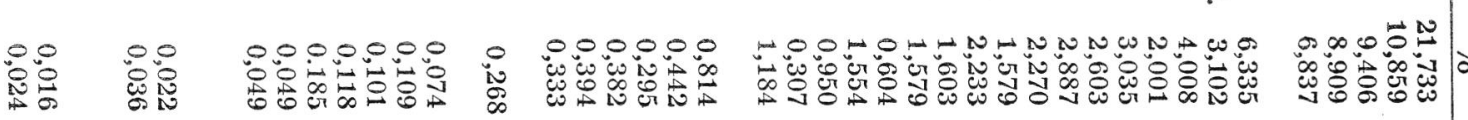
t⿹

空

F $N$ Z en Z Z

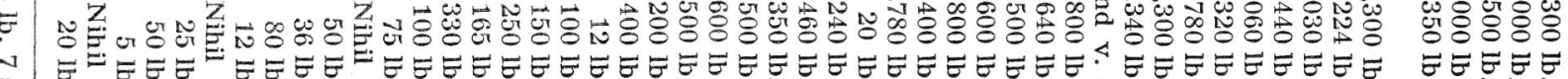
事

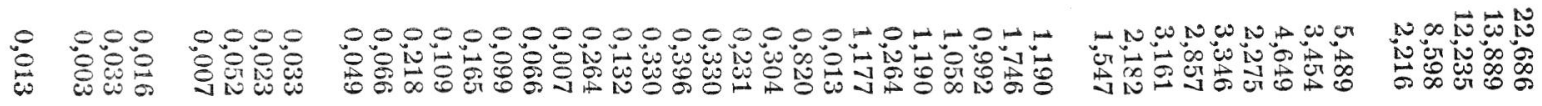

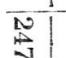

w 等

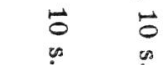
$\overrightarrow{0}$
0
0

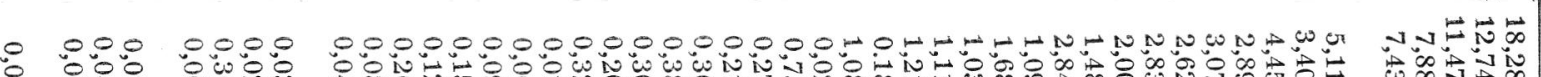

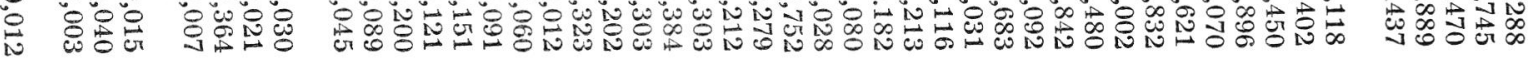

H

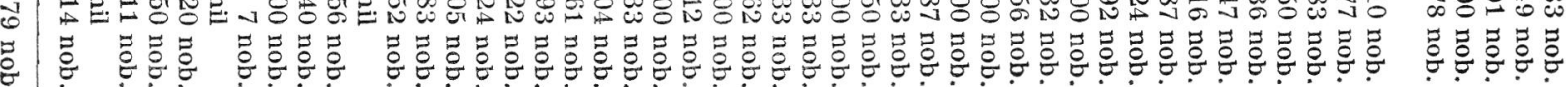

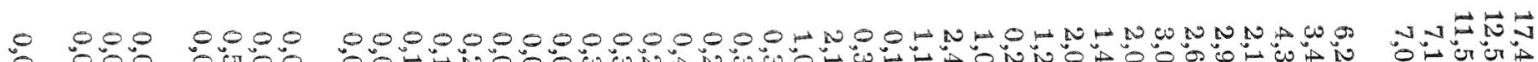

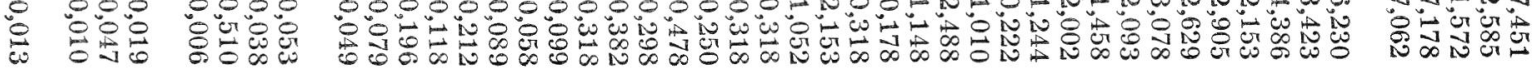

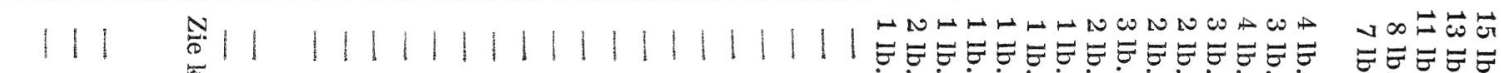

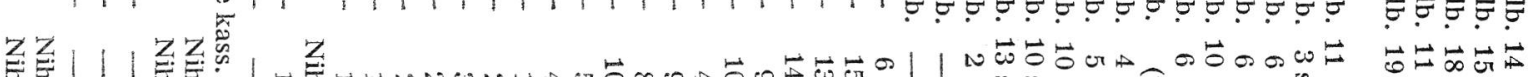

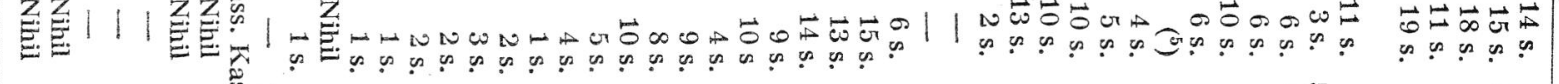

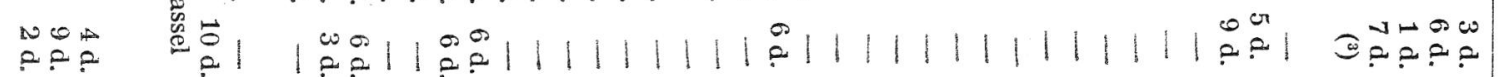

